\title{
Bölgesel Kalkınmada Yatırım ve Verimlilik: TRA1 Bölgesi İçin Hesaplanabilir Genel Denge Modeli Analizi ${ }^{1}$
}

Investment and Productivity in Regional Development: Analysis of Computable General Equilibrium Model For TRA1 Region

Muammer YAYLALI ${ }^{2}$

Zeynep KARACA ${ }^{3}$

Geliş tarihi: 01.12.2018, Kabul tarihi: 20.01.2019, Basım tarihi: 01.05.2019

Öz

Bölgesel kalkınmada yatırım ve verimlilik artışlarının etkisini araştıran bu çalısmada, hesaplanabilir genel denge modeli kullanılarak iki farklı senaryo test edilmiştir. Senaryolar TRA1 Düzey 2 Bölgesi (Erzurum-Erzincan-Bayburt) için uygulanmıştır ve çalışmanın veri altyapısını 2016 yll güncel sosyal hesaplar matrisi oluşturmaktadır. Birinci senaryoda kamu ve özel kesim yatırımlarındaki artışın, ikinci senaryoda ise yatırım artışlarının verimlilik artışı ile desteklenmesinin bölgenin istihdam, katma değer, ortalama ücret ve bölge içi tüketim değerleri üzerine olan etkisi araştırlmışıı. Senaryo 1 sonucuna göre, yatırım artışı, tarımsal istihdamı daha fazla artıracak, katma değer artışı daha az olacak, TRA1 bölgesi ile diğer bölgeler arasındaki ortalama ücret farkı giderek artacak ve bölgeiçi tüketim tarımsal ürünlere kayacaktır. Senaryo 2 sonucuna göre, yatııım artışının verimlilik artışı ile desteklenmesi, tarımdışı istihdamı daha fazla artıracak, katma değer artı̧ı daha fazla olacak, TRA1 bölgesi ile diğer bölgeler arasindaki ortalama ücret farkı giderek azalacak ve bölgeiçi tüketim tarımdışı ürünlere kayacaktır. Kurgulanan modelin çözümü ile yatırımların verimlilik artışı ile desteklenmesinin bölge ekonomisi için sadece yatııım artışından daha etkili olduğu ve yatırımların artırlmasının yanısıra verimliliği artırıcı politikalara ağıllık verilmesi gerektiği sonucuna ulaşılmışıtr.

Anahtar Kelimeler. Bölgesel Kalkenma, Hesaplanabilir Genel Denge, Kamu Yatrrmı, Özel Yaturm, Toplam Faktör Verimliliği.

Jel Kodlar1: D57, D58

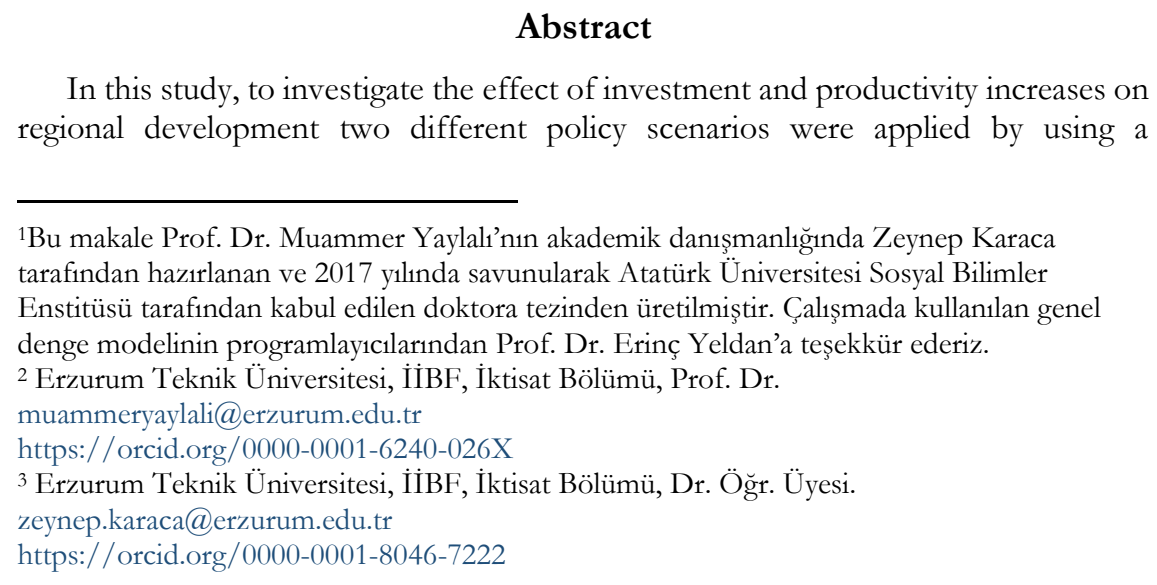

Abstract

In this study, to investigate the effect of investment and productivity increases on regional development two different policy scenarios were applied by using a

\footnotetext{
${ }^{1}$ Bu makale Prof. Dr. Muammer Yaylalı'nın akademik danışmanlığında Zeynep Karaca tarafindan hazırlanan ve 2017 yılında savunularak Atatürk Üniversitesi Sosyal Bilimler Enstitüsü tarafından kabul edilen doktora tezinden üretilmiştir. Çalışmada kullanılan genel denge modelinin programlayıcılarından Prof. Dr. Erinç Yeldan'a teşekkür ederiz.

${ }^{2}$ Erzurum Teknik Üniversitesi, İ̈BF, İktisat Bölümü, Prof. Dr.

muammeryaylali@erzurum.edu.tr

https://orcid.org/0000-0001-6240-026X

${ }^{3}$ Erzurum Teknik Üniversitesi, İİBF, İktisat Bölümü, Dr. Öğr. Üyesi.

zeynep.karaca@erzurum.edu.tr

https://orcid.org/0000-0001-8046-7222
} 
computable general equilibrium model. The scenarios have been implemented for TRA1 Level 2 Region (Erzurum-Erzincan-Bayburt) and the data utilized in the study was composed of the actual social accounting matrix for 2016. In the first scenario, the effect of the increase in public and private sector investments and in the second scenario, the effect of the investment increases sourced by the productivity increase has been investigated on the region's employment, added value, average wage and intra-regional consumption values. According to the result of scenario 1, increases in investment would enhance agricultural employment even more, the increase in added value would be less, average wage differential between TRA1 region and other regions would gradually increase and the intra-regional consumption would shift to agricultural products. According to the result of scenario 2, supporting investment increase sourced by increased productivity would enhance non-farm employment even more, the increase in added value would be more, average wage differential between TRA1 region and other regions would gradually decrease and the intraregional consumption would shift to non-agricultural products. It has been concluded that supporting the investments with increased productivity would be more effective than only investment increases for the region's economy and that the policies increasing productivity should be targeted besides investment increase.

Keywords: Regional Development, Computable General Equilibrium, Public Investment, Private Investment, Total Factor Productivity.

Jel Codes: D57, D58

\section{Giriş}

Kalkınma, bölgesel veya ulusal bir ekonomide üretim aktiviteleri, katma değer, kurumlar, hanehalkları arasındaki bütünsel ilişkiyi ve bu unsurların toplam kapasitelerindeki iyileşmeyi ifade etmektedir. Bir ülkede tüm bölgeler farklı düzeyde gelir, istihdam oranı, verimlilik, karşılaştırmalı üstünlükler ve kalkınma seviyelerine sahip olduğundan bölgesel kalkınma ekonomistlerin ilgi odağ1 haline gelmektedir. Bölgesel kalkınmada önemli araçlardan biri yatırımlardır. Bir bölge veya ülkeye yapılan kamu ve özel kesim yatırımları ile verimlilik arasında güçlü bir ilişki vardır. Kamu kesimi tarafindan yapılan yatırımlar azaldığında verimlilikte azalmaktadır. Kamu yatırımlarının bölgesel ekonominin gelişmesine olan katkısı, bu yatırımların üretimi etkilemesinden ve özel kesim yatırımlarını bölgeye çekmesinden kaynaklanmaktadır.

Verimlilik; rekabeti artırır ve bu da eş zamanlı olarak büyümeyi artırmaktadır, reel ücretleri artırır ve bu da yaşam standardındaki artışın temel belirleyici faktörüdür, çıkt1/girdi oranını artırır böylece mal ve hizmetlerin fiyat artışı daha az olur, mal ve hizmetlerin ticaretini daha kolay hale getirerek sosyal refahın artmasına katkı sağlamaktadır (Munnell, 1990:6).

TRA1 bölgesinde nüfusun \%51,7'si tarım sektöründe istihdam etmektedir, tarım sektörünü, hizmetler ve sanayi sektörü takip etmektedir. Sanayi sektöründe istihdam edilenlerin sayısı giderek artmasına rağmen Türkiye ortalamasının altındadır. Sanayi sektöründeki gelişmeler, yüksek ekonomik 
performansa ve böylece yüksek rekabet gücüne sahip olabilmeyi sağlayacağından bölgede verimliliğin artması gerektiği göze çarpmaktadır.

Bu çalışmanın amac1, Türkiye için güncel olan bir sosyal hesaplar matrisi (SHM) kullanılarak, yatırım ve verimlilik artışlarının bölgesel düzeyde etkisini analiz etmektir. TRA1 Düzey 2 Bölgesi için kurgulanan hesaplanabilir genel denge modelinde iki farkl senaryo test edilmiştir. Birinci senaryoda kamu ve Özel kesim yatırımlarının arttığ1, ikinci senaryoda yatırım artışının verimlilik artışı ile desteklendiği varsayılmaktadır. Çalışma TRA1 Düzey 2 Bölgesini kapsamaktadır ve 2016 yılı SHM'si çalışmanın veri altyapısını oluşturmaktadır. Model yıllar bazında ileriye doğru eşanlı denklemler aracılığıyla çözülmekte ve senaryo sonuçları 2016-2023 dönemini içermektedir.

Hesaplanabilir genel denge modeli çalışmalarının az sayıda olmasından ve bölgesel düzeyde bir genel denge modeli niteliği taşımasından dolay1 çalışmanın bu alana katkı sağlayacağı söylenebilir. Çalışmanın veri seti için oluşturulan SHM, Türkiye için en güncel sosyal hesaplar matrisi olma özelliğini taşımaktadır ve bir Düzey 2 bölgesi için oluşturulan ilk matristir. Hesaplanabilir genel denge modelciliğinin ilk adımı veri setinin oluşturulması olduğundan bu aşamaların tümünü içermesi yönüyle çalışma hesaplanabilir genel denge modeli uygulamalarının bütüncül bir çerçeve içinde değerlendirilmesine imkân tanımaktadır.

Bölgesel sorunların çözülmesine katkı sağlayabilecek çeşitli politikaların etkilerinin, geliştirilen veri altyapısı ile çözülebilmesi için sektörlerin, hanehalkı hesabının, firma hesaplarının daha detaylandırılması faydalı olacaktır. Örneğin hizmet sektörünün tarım-dışı içinde yer alması bazı dezavantajlar oluşturabilir. Ancak bölgesel düzeyde veri yetersizliğinden dolay1, sosyal hesaplar matrisinin iki bölgeli hale getirilmesinde zorluk yaşanacağından, bu çalışmada hanehalkı ve firma hesabı birleştirilip özel kesim hesabı olarak ele alınmakta ve tarım ve tarım dışı olmak üzere iki sektörlü bir yap1 tercih edilmektedir.

\section{Literatür Özeti}

Yatırım ve toplam faktör verimliliği ilişkisini araştıran çalışmalardan bazılarına bu kısımda yer verilecektir.

Kamu yatırımları ile bölgesel gelişme arasındaki ilişkiyi araştıran başlıca çalışma Hansen (1965) çalışmasıdır. Hansen yatırımları üretim süreciyle ilgili olan yatırımlar ve diğer yatırımlar (sosyal yatırımlar ve ekonomik yatırımlar) şeklinde ayırmıştır. Sosyal yatırımların geri kalmış bölgelerde, ekonomik yatırımların orta seviyede gelişmiş olan bölgelerde (hammadde, nitelikli işgücü avantaj1 olan bölgeler) daha etkili olduğu sonucuna ulaşmıştır. Kamu yatırımlarının verimli olup olmadığ1 tartışması Aschauer (1989) ile gündeme gelmiştir. Aschauer, ABD'de verimliliğin kamu yatırımları ile açıklanıp açıklanamayacağını araştırdığında kamu yatırımlarının verimliliği açıklayan en 
önemli değişken olduğu sonucuna varmıştır. Aschauer, kamu yatırımlarının üretimdeki değişikliği açıklamada anahtar bir role sahip olduğunu ve verimlilikteki azalmanın yatırımlardaki azalmayla açılanabileceğini göstermiştir. Munnell (1990), 1970’lerde işgücü verimliliğindeki yavaşlamanın nedenini araştırdığında kamu yatırımlanı ile işgücü verimliliği arasında güçlü bir ilişki bulmuştur. Bölgesel düzeyde bu ilişkinin araştırılması veri yetersizliğinden dolayı sınırlı kalmasına rağmen bazı çalışmalar mevcuttur. Garcia-Mila (1992), yatırımların eyalet genelinde üretim fonksiyonu üzerindeki etkisini araştırmıstır. Bu yatırımların üretim üzerinde pozitif etkisi olduğunu görmüsstür.

Gelişmekte olan ülkelerde kamu ve özel kesim yatırımlarının büyümeye olan etkisi giderek ilgi odağı haline gelmektedir. Genel olarak bu ülkelerde kamu yatırımlarının özel kesim yatırımlarının verimliliğini artıracağı ve bunun da büyümeye katkı yapacağı belirtilmektedir. Gelişmekte olan ülkeler için yapılan bazı çalışmalarda, kamu yatırımlarının büyüme üzerinde özel yatırımlar kadar etkili olmadığı tespit edilmiştir (Coutinho ve Gallo, 1996; Khan ve Kumar, 1993; Serven ve Solimano, 1990). Bazı araştırmacılar da bu etkinin negatif olabileceğini savunmuşlardır. (Khan ve Reinhart, 1990). Ancak bu çalışmalar yatırımların toplam faktör verimliliği üzerindeki etkisini dikkate almamıştır.

Kaynak kullanımının etkinliği için kullanılan toplam faktör verimliliği artık olarak hesaplanır. Toplam faktör verimliliği önemli olmasına rağmen gelişmekte olan ülkelerde verimliliği belirleyen çalışmalar az sayıdadır. Bu konu üzerine yapılan çalş̧malarda toplam kamu harcamaları ile verimlilik arasında negatif bir ilişki bulunmuştur, fakat yatırım ve verimlilik ilişkisi araştırılmamıştır (Gallagher, 1991; King ve Levine, 1992; Odedokun, 1992). Yatırım ve verimlilik ilişkisini araştıran çalışmalarda mevcuttur. Yatııım ve verimlilik ilişkisi çoğunlukla ekonometrik yöntemler kullanılarak tahmin edilmiştir. Costa vd. (1987) ekonometrik bir yöntemle üretim fonksiyonu tahmin etmişlerdir. Lynde ve Richmond (1993), durağan olmayan zaman serisi yöntemini kullanarak kamu yatırımlarındaki bir azalmanın verimliliği \%40 azalttığını bulmuşlardır. Lu (1996), Çin için bir üretim fonksiyonu tahmin etmiştir. Khan ve Kumar (1997), toplam faktör verimliliğini belirlemek için kamu ve özel kesim yatırımlarının yanında enflasyon, dış ticaret haddi değişkenlerini kullanarak bir analiz gerçekleştirmiştir. Buna göre kamu ve özel kesim yatırımlarının toplam faktör verimliliğini artırdığ sonucuna ulaşmışıır. Calderón ve Servén (2004) bir dizi ekonometrik metodoloji kullanarak 19602000 dönemini kapsayan 100 ülke için yatırımların ekonomik gelişme üzerindeki etkisini araştırmıslardır. Etkin ve verimli yatırımların gelir eşitsizliğini azalttığını ve ekonomik büyümeyi pozitif etkilediğini tespit etmişlerdir. Bu çalısmaya ek olarak Aghian ve Howitt (2009), Ghazanchyan ve Stotsky (2013), Gupta vd. (2014)'de yatırımların verimli kullanıldığ1 ülkelerde yatırım ve büyüme arasında güçlü bir ilişki olduğunu tespit 
etmişlerdir. Literatürde yatırım ve verimlilik arasında negatif yönlü ilisski olduğunu gösteren çalışmalar (Hulten ve Schwab, 1984) olsa da çoğunlukla pozitif ilişki olduğu bulunmuştur.

Diğer bazı çalışmalar arasında Duffy-Deno ve Eberts, 1991; Munnell, 1992; Yamano ve Ohkawara, 2000; Rosik, 2006; Márquez vd. 2011 sayllabilir.

Yatırım ve verimlilik ilişkisi ayrıca hesaplanabilir genel denge modelleri kullanılarak da araştırılmıştır. Johansen (1960) genel denge modelinin ilk başarılı uygulamasını gerçekleştirmiştir. Zamanla hesaplanabilir genel denge modellerinin politika değerlendirmeleri için gelişimi ve kullanımı önemli bir literatür oluşmasına yol açmışır. Hesaplanabilir genel denge modelleri yaygın hale gelmesine rağmen bölgesel düzeyde model kurgulamak formülleştirme ve veri bulma zorluklarıla karşılaşmaktadır. Bölgesel modellerin belirlenmesinde bölgesel dinamikler, işgücü piyasası ve parametre gibi konuların eksikliği söz konusudur. Ancak bölgesel parametrelerin eksikliği, yerel veya coğrafi olarak ağırlıklandırma ile giderilmektedir. Bilgisayar teknolojisindeki gelişmeler de bu modellerin çözümünü kolay hale getirmektedir. Böylece genel denge modellerinin bölgesel politikaların etkisini görmek için kullanılması (Bautista, 1988; Upadhyaya, 1995; Kim ve Kim, 2002; Kim ve Kim, 2003; Fougere vd., 2004; Liu, 2006; Wang vd., 2010; Sakamoto, 2012; Thaipraset vd., 2013; Mostert ve Heerden, 2015) giderek artmaktadır. Hesaplanabilir genel denge modelleri ekonominin bir bütün olarak ele alınmasına imkân verdiğinden daha gerçekçi sonuçlar üretilmesini sağlamaktadır.

Türkiye'de hesaplanabilir genel denge modelinin gelişimine katkı sağlayan Kalkınma Bakanlığı uzmanlarından Telli (2004) Türkiye ekonomisi için makro düzeyde reel sosyal hesaplar matrisi üretilmesi için tutarlı bir çerçeve geliştirmiştir. Hesaplanabilir genel denge modellerine yönelik çalışmaların en önemli sorunu tutarlı veri tabanlarının geliştirilmesi olduğundan Telli tarafindan oluşturulan yöntem 2004 yılı ve sonrasında yapılan çalışmaların birçoğunda kullanılmaktadır. Çavdaroğlu (2007) da reel sosyal hesaplar matrisinin finansal sosyal hesaplar matrisine dönüştürülebilmesi için mali fon akım tablolarını oluşturmuştur. Erten (2009) ise reel sosyal hesaplar matrisi kurgusunun makro düzlemden daha detaylı sektörel düzleme taşınmasını sağlamıştır. Erten, veri altyapısını oluştururken sadece bir yıla ilisskin SHM oluşturulmasının ötesine geçerek iki farklı yıla ait girdi çıktı tablosu yapısının bir arada kullanılmasıyla yeniden uygulanabilir tutarlı bir yöntemsel çerçeve geliştirmiştir. Oluşturulan tutarlı veri altyapısıyla istihdamsız büyüme sorununa çözüm olabilecek alternatif politika senaryolarının genel ekonomi üzerindeki etkilerinin belirlenmesi mümkün olmaktadır. Yeldan vd. (2012) tarafindan kurgulanan model Türkiye için ilk bölgesel genel denge modelidir. Yeldan vd. (2012) tarafindan yapilan çalışmada, nüfus ve fert başına gelir esasına dayalı olarak Türkiye'yi iki büyük bölgeye (doğu ve batı) ayırarak, 
Türkiye girdi çıtı tablosunu ve sosyal hesaplar matrisini iki bölgeli ve iki sektörlü bir yapıda ele alarak ve hesaplanabilir genel denge modeli ile bölgesel politika araçlarının etkisi analiz edilmeye çalışılmışır. İlk senaryoda kamu yatırım tahsislerinin doğu lehine büyük miktarda artış gösterdiği varsayılmıştır. İkinci senaryoda ise doğu bölgesinin ihracat dişsallı̆̆ındaki değişimin etkisi görülmeye çalışılmıştır. Elde edilen sonuçlara göre, doğu bölgesinin ihracat kapasitesindeki artış ücretler üzerinde kamu yatırımlarına göre daha etkilidir. Her iki senaryoda da batı bölgesinde işsizlik oranları baz senaryoya göre daha hızlı düşüş göstermiştir.

Bu çalışmada bir Düzey 2 bölgesi için sosyal hesaplar matrisi kurulması amaçlandığından, ilk olarak Türkiye için oluşturulan matris farklı kaynaklardan verilerin kullanılmasıyla iki bölgeli hale getirilmiştir. Türkiye için oluşturulan matris en güncel matris olma özelliğini taşımaktadır, bu matristen hareketle elde edilen bölgesel matris ise bir Düzey 2 bölgesi için oluşturulan ilk matristir. Tutarlı bir veri altyapısının elde edilmesiyle istenilen bölgesel politikaların etkisi analiz edilebilecektir. Oluşturulan bu matris referans alınarak diğer Düzey 2 bölgeleri için de sosyal hesaplar matrisi elde edilerek çeşitli politikaların genel ekonomi üzerindeki etkilerinin hesaplanabilir genel denge modeli çerçevesinde çözülmesi mümkün olacaktır.

\section{Yöntem ve Veri Seti}

\subsection{Bölgesel Düzeyde 2012 Yılı Girdi Çıktı Tablosu}

İki bölgeli şekilde oluşturulan girdi çıktı tablosunda bölgesel kırllım "Bölge + (Türkiye eksi Bölge)" şeklinde oluşturulmuştur. Böylece o bölgeye ait hesapların iki defa kullanılmasının önüne geçilebilmektedir. Bu çalışmada "TRA1 + (TÜRKIYE eksi TRA1)" girdi çıtı tablosu oluşturulmuştur. Bundan sonraki hesaplamalarda Bölge 1 olarak TRA1 ve Bölge 2 olarak (Türkiye eksi TRA1) kastedilmektedir.

Türkiye için en güncel girdi çıtı tablosu TÜIKK tarafından 14.12.2016 tarihinde güncellenen 2012 yllına ait temel fiyatlarla 64 sektörlü girdi çıktı tablosudur. Bu çalışmada kullanacağımız bölgesel hesaplanabilir genel denge modeli için Türkiye 64 sektörlü 2012 Girdi Çıktı tablosu tarım ve tarım dışı olmak üzere iki sektörlü yapıya dönüştürülmüştür. Bu yapının tercih edilmesinin sebebi iki sektörden fazla sektörlü modellerde veri temininde yaşanan güçlükler ve sektörlere verilecek dişsal şokların daha çok tarım ve tarım dışı ayrımında kendini gösterecek olmasıdır. Sektörlerin toplulaştıılması işlemi Ulusal Hesaplar Sistemi'ne göre yapılmıştır. Tablo 1'de 2012 yllına ait Türkiye için toplulaştırılmış iki sektörlü girdi çıktı tablosu yer almaktadır.

Türkiye girdi çlktı tablosunun iki bölgeli yapıya dönüştürülmesi işleminde, TÜIKK tarafından yyınlanan il bazında GSYH verileri kullanılmıştır. 2012 yılına ait il bazında üç sektörlü (tarım, sanayi, hizmet) Gayri Safi Yurtiçi Hasıla verileri ve vergi eksi sübvansiyonları içeren tablo önce tüm Düzey 2 
Bölgesel Kalkınmada Yatırım ve Verimlilik: TRA1 Bölgesi İçin Hes...

Bölgelerini gösterecek şekilde tarım ve tarım dişı olarak toplulaştırılmıştır. Elde edilen bu tablo Tablo 2'de sunulmaktadır. 
Tablo 1. 2012 Türkiye Toplulaştırılmıs İki Sektörlü Girdi Çıktı Tablosu (Cari Temel Fiyatlarla)

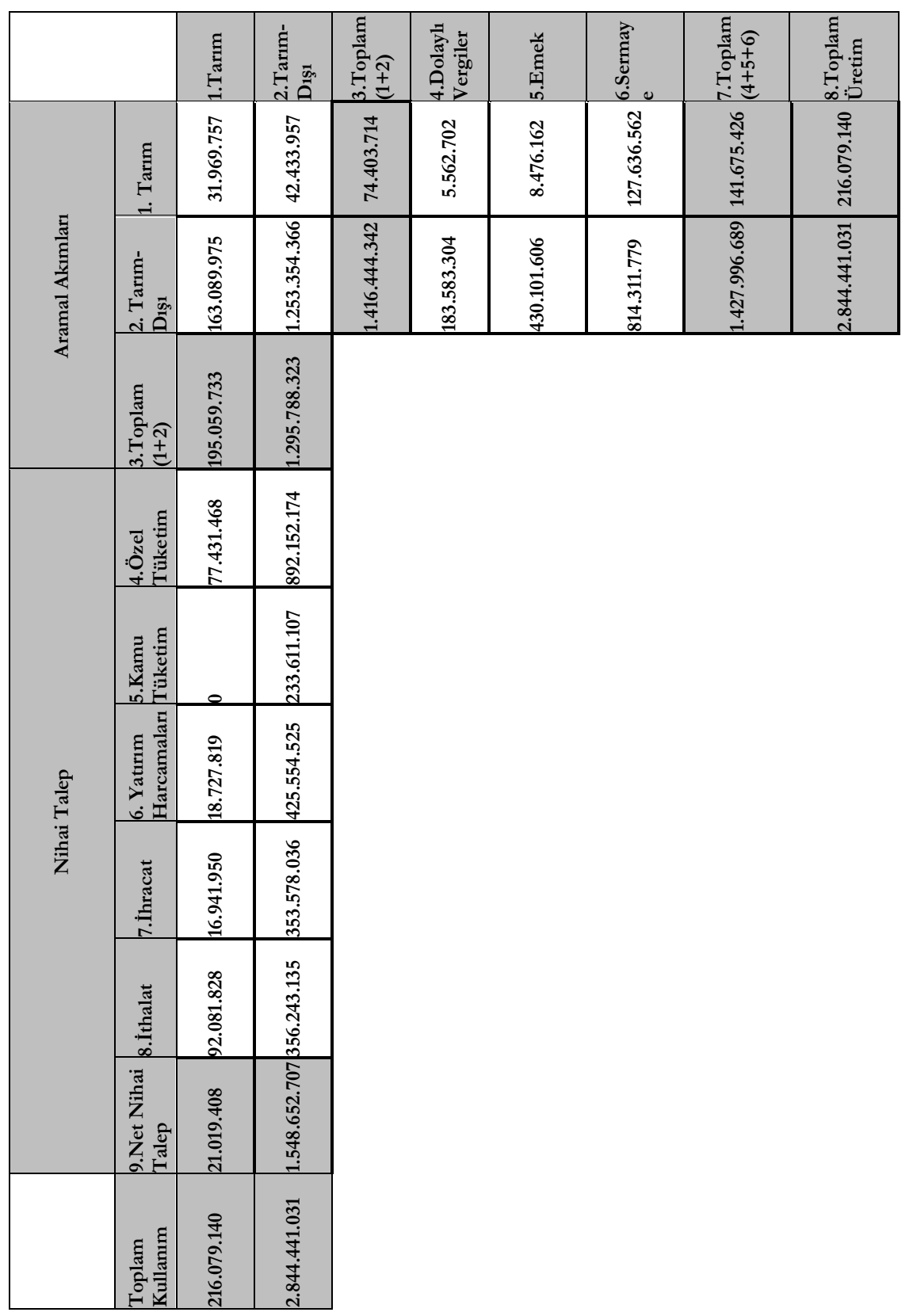

Not: Yuvarlama nedeniyle toplamda farkliliklar olabilir

Kaynak: TÜİK verilerine dayalı olarak yazar tarafından hesaplanmıştır. 
Tablo 2. Düzey 2 Bölgeleri İtibariyle GSYH Değerleri, 2012, TL

\begin{tabular}{|l|l|l|l|l|l|}
\hline $\begin{array}{c}\text { İstatistiki } \\
\text { Bölge } \\
\text { Birimleri } \\
\text { Sınılamas1 }\end{array}$ & Tarım & Tarım-Diş1 & $\begin{array}{l}\text { Sektörler } \\
\text { toplam1 }\end{array}$ & $\begin{array}{l}\text { Vergi- } \\
\text { sübvansiyon }\end{array}$ & GSYH \\
\hline TÜRKIYE & 121.692 .893 & 1.263 .719 .876 & 1.385 .412 .768 & 184.259 .347 & 1.569 .672 .115 \\
\hline TR10 & 782.857 & 419.251 .845 & 420.034 .701 & 55.864 .448 & 475.899 .149 \\
\hline TR21 & 3.874 .279 & 28.998 .143 & 32.872 .422 & 4.372 .019 & 37.244 .441 \\
\hline TR22 & 5.509 .734 & 22.371 .681 & 27.881 .415 & 3.708 .217 & 31.589 .633 \\
\hline TR31 & 4.848 .080 & 81.695 .874 & 86.543 .954 & 11.510 .311 & 98.054 .265 \\
\hline TR32 & 8.238 .274 & 37.653 .999 & 45.892 .273 & 6.103 .654 & 51.995 .927 \\
\hline TR33 & 10.675 .469 & 34.417 .519 & 45.092 .987 & 5.997 .349 & 51.090 .337 \\
\hline TR41 & 4.983 .575 & 70.130 .167 & 75.113 .742 & 9.990 .098 & 85.103 .839 \\
\hline TR42 & 3.899 .478 & 74.099 .899 & 77.999 .377 & 10.373 .886 & 88.373 .263 \\
\hline TR51 & 2.848 .483 & 125.049 .973 & 127.898 .456 & 17.010 .444 & 144.908 .900 \\
\hline TR52 & 7.287 .582 & 24.263 .653 & 31.551 .235 & 4.196 .302 & 35.747 .537 \\
\hline TR61 & 7.336 .724 & 47.978 .428 & 55.315 .152 & 7.356 .893 & 62.672 .045 \\
\hline TR62 & 7.586 .839 & 45.961 .854 & 53.548 .693 & 7.121 .955 & 60.670 .648 \\
\hline TR63 & 4.740 .979 & 29.404 .054 & 34.145 .032 & 4.541 .276 & 38.686 .308 \\
\hline TR71 & 4.562 .959 & 14.403 .524 & 18.966 .483 & 2.522 .535 & 21.489 .018 \\
\hline TR72 & 4.979 .081 & 28.722 .430 & 33.701 .512 & 4.482 .288 & 38.183 .799 \\
\hline TR81 & 966.229 & 11.967 .406 & 12.933 .635 & 1.720 .168 & 14.653 .803 \\
\hline TR82 & 2.407 .397 & 7.762 .963 & 10.170 .359 & 1.352 .654 & 11.523 .013 \\
\hline TR83 & 7.310 .251 & 26.576 .298 & 33.886 .549 & 4.506 .898 & 38.393 .446 \\
\hline TR90 & 4.773 .186 & 28.028 .333 & 32.801 .519 & 4.362 .589 & 37.164 .108 \\
\hline TRA1 & 2.590 .685 & 10.280 .388 & 12.871 .073 & 1.711 .848 & 14.582 .920 \\
\hline TRA2 & 3.222 .773 & 6.152 .187 & 9.374 .960 & 1.246 .866 & 10.621 .826 \\
\hline TRB1 & 2.602 .551 & 16.161 .479 & 18.764 .030 & 2.495 .609 & 21.259 .639 \\
\hline TRB2 & 3.414 .977 & 12.805 .881 & 16.220 .857 & 2.157 .368 & 18.378 .225 \\
\hline TRC1 & 2.741 .013 & 24.408 .369 & 27.149 .381 & 3.610 .857 & 30.760 .238 \\
\hline TRC2 & 6.376 .283 & 19.898 .821 & 26.275 .104 & 3.494 .578 & 29.769 .683 \\
\hline TRC3 & 3.133 .157 & 15.274 .709 & 18.407 .866 & 2.448 .239 & 20.856 .105 \\
\hline
\end{tabular}

Kaynak: TÜİK verilerine göre yazar tarafindan toplulaştırılmıştır.

Tablo 2'de görüldüğ̈ gibi Türkiye'nin 2012 yllı GSYH'si 1.569.672.115 TL iken TRA1 Düzey 2 Bölgesi'nin 2012 yllına ait GSYH değeri 14.582.920 TL'dir. Vergi eksi sübvansiyon değeri (net vergiler) ise 1.711.848 TL'dir. Bölgenin Türkiye'nin GSYH'sina katkısı sadece \%1 düzeyindedir. Bu durum göç oranının yüksek ve toplam faktör verimliliğinin düşük olduğu bölgenin üretim yapısı ve refah düzeyi bakımından geride kalan bölgelerden biri olduğunu göstermektedir. 
Tablo 3. TRA1 Bölgesi Aramal Akımları, 2012 (TL)

\begin{tabular}{|l|l|l|l|}
\hline & Tarım & Tarım D1ş1 & Toplam \\
\hline Tarım & 680.595 & 3.471 .975 & 4.152 .570 \\
\hline Tarım D1ş1 & 345.201 & 10.196 .065 & 10.541 .266 \\
\hline Toplam & 1.025 .796 & 13.668 .040 & 14.693 .836 \\
\hline
\end{tabular}

Kaynak: Yazarın Kendi Hesaplamaları.

Tablo 3'e göre TRA1 Düzey 2 Bölgesi tarımsal üretimini gerçekleştirmek için tarım sektöründen 680.595 TL ve tarım dışı sektörden 345.201 TL değerinde ara girdi kullanmaktadır.

Ulusal girdi çıktı tablosunda yer alan ihracat rakamlarının iki bölgeye ayrılması işleminde TÜİK tarafindan yayınlanan Düzey 2 Bölgelerine ait ihracat rakamları kullanılmıstır. Bölge 1 ve Bölge 2'ye ait 2012 yılı ihracat rakamlar1 Tablo 4'te gösterilmektedir.

Tablo 4. Sektörel İhracat İstatistikleri, 2012 (TL)

\begin{tabular}{|l|l|l|}
\hline & Tarım & Tarım D1ş1 \\
\hline TRA1 (Bölge 1) & 1.740 & 118.936 \\
\hline $\begin{array}{l}\text { Türkiye eksi TRA1 } \\
\text { (Bölge 2) }\end{array}$ & 16.940 .210 & 353.459 .100 \\
\hline Türkiye & 16.941 .950 & 353.578 .036 \\
\hline
\end{tabular}

Kaynak: TÜİK verilerine göre yazar tarafından toplulaştırılmıştır.

Buna göre Türkiye'nin tarım ve tarım dışı ihracatı sırasıyla 16.941.950 TL ve 353.459.100 TL iken TRA1 Düzey 2 Bölgesinin ihracat rakamlar1 1.740 TL ve 118.412 TL'dir. Modelde tek bir arz piyasası olduğu kabul edildiğinden ithalatta bölgesel bir ayrıma gidilmemiştir.

Ulusal gayrisafi katma değer içinde TRA1 bölgesinin payını gösteren hesapların belirlenebilmesi için tarım ve tarım dişı sektörlerde TRA1 bölgesinin işgücü (emek - L) ve sermaye (işletme artığ1 - K) paylarının tespit edilmesi gerekmektedir. Ulusal girdi çıktı tablosunda üretim faktörü olarak yer alan emek değerlerinin iki bölgeye ayrılması işleminde TÜİK tarafindan yayınlanan Düzey 2 Bölgelerine ait sektörel istihdam rakamları kullanılmıştır. Bölge 1 ve Bölge 2'ye ait 2012 yilı sektörel istihdam oranları Tablo 5'te gösterilmektedir.

Tablo 5. Sektörel İstihdam, 2012 (bin)

\begin{tabular}{|l|l|l|l|l|}
\hline & Tarım & Tarım Diş1 & Tarım (\%) & $\begin{array}{l}\text { Tarım D1ş1 } \\
\mathbf{( \% )}\end{array}$ \\
\hline TRA1 (Bölge 1) & 128 & 179 & 1.233 & 0.956 \\
\hline $\begin{array}{l}\text { Türkiye eksi TRA1 } \\
\text { (Bölge 2) }\end{array}$ & 5.969 & 18.545 & 98.759 & 99.060 \\
\hline Türkiye & 6.097 & 18.724 & 100.00 & 100.00 \\
\hline
\end{tabular}


Not 1: Yuvarlama nedeniyle toplamda farkliliklar olabilir

Not 2: İnşaat sektörü sanayi sektörü içinde değerlendirilmiştir.

Kaynak: TÜİK verilerine göre yazar tarafindan toplulaştırılmıştır.

Tablo 5'te bölgenin istihdamının tarım ağırlıklı olduğu ve Türkiye içinde istihdam oranının ne kadar düşük olduğu görülmektedir. Bölge için elde edilen emek bloğu Tablo 6'da sunulmaktadır.

Tablo 6. Bölgesel İşgücü Bloğu, 2012 (TL)

\begin{tabular}{|l|l|l|l|}
\hline & Tarım & Tarım D1ş1 & Toplam \\
\hline TRA1 (Bölge 1) & 104.496 & 4.111 .738 & 4.216 .234 \\
\hline $\begin{array}{l}\text { Türkiye eksi } \\
\text { TRA1 (Bölge 2) }\end{array}$ & 8.371 .666 & 425.989 .868 & 434.361 .534 \\
\hline Toplam & 8.476 .162 & 430.101 .606 & 438.577 .768 \\
\hline
\end{tabular}

Kaynak: TÜİK verilerine göre yazar tarafından hesaplanmıştır.

Tablo 6'ya göre TRA1 bölgesi tarımsal üretim gerçekleştirmek için emeğe 104.496 TL ödeme yapmıştır. Tarım dışı üretimi gerçekleştirmek için ise 4.111.738 TL ödeme yapmıştır.

Katma değer hesabında yer alan sermaye (işletme artığı) hesabının bölgesel düzeyde elde edilmesinde Gelir İdaresi Başkanlığı tarafından yayınlanan 2012 dönemi Kurumlar Vergisi İl Toplamları tablosu kullanılmıştır.

Tablo 7. Kurumlar Vergisi Oranları, 2012 (TL)

\begin{tabular}{|l|l|l|l|}
\hline Bölge & $\begin{array}{l}\text { Mükellef Say1s1 } \\
\mathbf{( \% )}\end{array}$ & Matrah (\%) & $\begin{array}{l}\text { Tahakkuk } \\
\text { Eden (\%) }\end{array}$ \\
\hline TRA1 (Bölge 1) & 0,60 & 0,31 & 0,32 \\
\hline $\begin{array}{l}\text { Türkiye eksi } \\
\text { TRA1 (Bölge 2) }\end{array}$ & 99,40 & 99,69 & 99,68 \\
\hline Toplam & 100,00 & 100,00 & 100,00 \\
\hline
\end{tabular}

Kaynak: Gelir İdaresi Başkanlığı verilerine göre yazar tarafından hesaplanmıştır.

Tablo 7'ye göre Türkiye'deki mükelleflerin $\% 0,60$ ' 1 TRA1 bölgesinde yer alırken, tahakkuk eden kurumlar vergisi tutar1 \%0,32'dir. TRA1 bölgesindeki işletmelerin göreli olarak kazanç bakımından geri olduğu görülmektedir. Çalışmada bölge için işletme artığının hesaplanmasında tahakkuk eden kurumlar vergisi değişkeni kullanılmıştır. İşletme artığı bloğu Tablo 8'de sunulmaktadır.

Tablo 8. Bölgesel İşletme Artığ1 Bloğu, 2012 (TL)

\begin{tabular}{|l|l|l|l|}
\hline & Tarım & Tarım D1ş1 & Toplam \\
\hline TRA1 (Bölge 1) & 2.717 .218 & 6.624 .444 & 9.341 .662 \\
\hline $\begin{array}{l}\text { Türkiye eksi } \\
\text { TRA1 (Bölge 2) }\end{array}$ & 124.919 .344 & 807.687 .335 & 932.606 .679 \\
\hline Toplam & 127.636 .562 & 814.311 .779 & 941.948 .341 \\
\hline
\end{tabular}

Kaynak: TÜİK verilerine göre yazar tarafindan hesaplanmıstır. 
Tablo 8'e göre TRA1 bölgesi tarımsal üretim gerçekleştirmek için sermayeye 2.717.218 TL ödeme yapmıştır. Tarım dışı üretimi gerçekleştirmek için ise 6.624.444 TL ödeme yapmıştır.

Bölgesel girdi çıtı tablosu elde edilirken bir diğer aşama olan vergi eksi sübvansiyonlar hesabının da Bölge 1 ve Bölge 2 için elde edilmesi gerekmektedir. Bunu gerçekleştirirken TÜIKK tarafından il bazında yayınlanan GSYH tablolarında ifade edilen vergi-sübvansiyonlar hesab1 oranları kullanılmıştır.

\section{Tablo 9. Bölgesel Vergi Bloğu, 2012 (TL)}

\begin{tabular}{|l|l|l|l|}
\hline & Tarım & Tarım D1ş1 & Toplam \\
\hline TRA1 & 118.423 & 1.493 .454 & 1.611 .877 \\
\hline $\begin{array}{l}\text { Türkiye eksi } \\
\text { TRA1 }\end{array}$ & 5.444 .279 & 182.089 .850 & 187.534 .129 \\
\hline Toplam & 5.562 .702 & 183.583 .304 & 189.146 .006 \\
\hline
\end{tabular}

Kaynak: TÜİK verilerine göre yazar tarafından hesaplanmışır.

Yukarıdaki hesaplamalar neticesinde nihai olarak elde edilen iki bölgeli girdi çıktı tablosu Tablo 10'da sunulmaktadır.

Tablo 10'a göre Bölge 1'de tarım ve tarım diş1 sektörler kendi üretimlerini gerçekleştirebilmek için sırasıyla 680.595 TL ve 3.471.975 TL'lik tarım ürününü ara mal olarak kullanmışlardır. Benzer şekilde Bölge 1'de tarım sektörü, sanayi ve hizmetler sektöründen (tarım dışı) 345.201 TL tutarında tarım dışı mal almış ve kendi çıktısını üretmek için ara mal olarak kullanmışıır. Tarım dışı sektör üretimini gerçekleştirmek için emek ve sermaye olmak üzere iki temel girdi kullanmış ve emek için 4.111.738 TL, sermaye için 6.624.444 TL ödeme yapmıştır. Ayrıca Tablo 10'da görüldügüü üzere Bölge 2'nin tarımsal istihdamdan aldığ1 pay oldukça düşük düzeydedir. Tarım dış1 istihdamda Bölge 2'nin önemli bir ağırlığı olduğu görülmektedir.

Gayrisafi yurtiçi hasıla hesaplandığında Türkiye'nin gayrisafi yurtiçi hasılasının 1.569.672.115 TL olduğu ve Bölge 1'in gayrisafi yurtiçi hasılasının 15.169.773 TL olduğu görülmektedir. TÜİK tarafından yayınlanan Bölge 1 gayrisafi yurtiçi hasılası 14.582 .920 'dir. Hata payının $\% 4$ olduğu kabul edilerek analizlere bu değerlerle devam edilmiştir. Benzer şekilde Türkiye için toplam net vergiler 189.146.006'dır. Bölge 1 için hesaplanan net vergiler ise 1.611.877'dir. TÜİK tarafından yayınlanan Bölge 1 net vergileri 1.711.848'dir ve burada da \%6'lık hata payı olduğu kabul edilmektedir. Çalışmada kullanılan baz yll verileri istatistiki olarak güven aralıkları olan $\% 10$ ve $\% 5$ limitlerinin altındadır. 2012 ylı iki bölgeli girdi çıktı tablosundaki nihai talep bileşenleri tarım ve tarım dışı olarak toplulaştırılmış, ancak bölgesel düzeyde bir ayrım yapilmamıştır. 
Bölgesel Kalkınmada Yatırım ve Verimlilik: TRA1 Bölgesi İçin Hes...

Tablo 10. Türkiye İki Bölgeli-İki Sektörlü (2X2) Girdi-Çıktı Tablosu, 2012

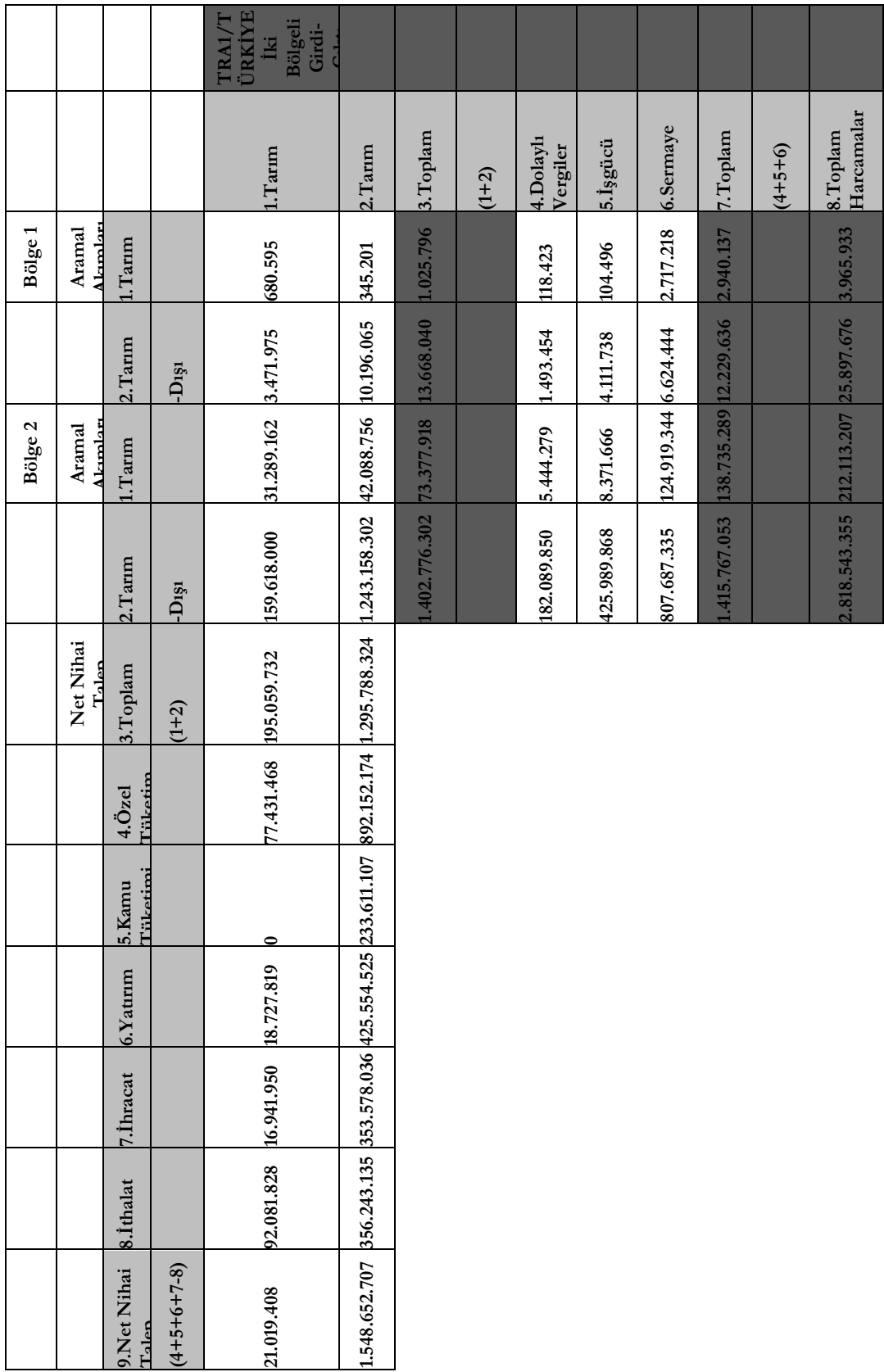




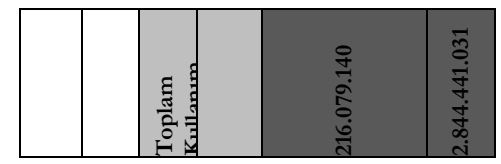

Kaynak: Yazarın Kendi Hesaplamaları.

\subsection{Sosyal Hesaplar Matrisinin Yapısı ve Elde Edilmesi}

Bölge 1- Bölge 2 girdi çlkt tablosu temelinde sosyal hesaplar matrisi üretilmiştir. Buna göre girdi çıktı tablosunda yer alan üretim faktörleri yani emek ve sermaye hesabı sosyal hesaplar matrisi içerisinde üretim faktörleri hesabında yer almaktadır. Girdi çıktı tablosundaki tarım ve tarım dışı sektörlerin aramalı akımları sosyal hesaplar matrisinde mal ve hizmet girdilerini teşkil etmektedir. Girdi çıktı tablosunda bulunan dolaylı vergiler hesab1 sosyal hesaplar matrisinde sosyal güvenlik dahil devlet hesabını oluşturmaktadır. Bölge 1 ve Bölge 2'nin faaliyetleri neticesinde üretilen vergiler de devlete gelir olarak yansımaktadır.

Hanehalkı hesabı girdi çıktı tablosunda bulunmayan ancak sosyal hesaplar matrisinde yer alması gereken bir hesaptır. Girdi çıtı tablosunda bulunmayıp sosyal hesaplar matrisinde yer alan bir diğer hesap dış alem hesabıdır.

Çalışmada kullanılan bölgesel sosyal hesaplar matrisi oluşturulurken Yeldan vd. (2012) tarafindan oluşturulan sosyal hesaplar matrisi şablonu kullanılmıştır. Oluşturulan sosyal hesaplar matrisi toplulaştırılmış olarak değerlendirildiğinde 6 satır ve 6 sütun bloğundan oluşmaktadır. Bu bloklar, üretim aktiviteleri, ulusal mal ve hizmet piyasaları, üretim faktörleri, ekonomik birimler, sermaye hesabı ve dış alem bloklarıdır.

Bu çalısmada kullanılan yapı açısından üretim aktiviteleri ve mal ve hizmet hareketleri tarım ve tarım dışı olarak iki sektöre ayrılmaktadır. Üretim faktörleri bloğu emek ve sermaye, ekonomik birimler bloğu özel sektör ve kamu sektörü, sermaye hesabı bloğu ise toplam yatırımlardan ve toplam tasarruflardan oluşmaktadır.

Sosyal hesaplar matrisinin tamamlanması için girdi çıktı tablosunda yer almayan bir takım hesapların farklı veri kaynaklarından temin edilip sosyal hesaplar matrisine işlenmesi gerekmektedir. Kalkınma Bakanllğı, Hazine Müsteşarllğı, Türkiye Cumhuriyet Merkez Bankası, Dünya Bankası ve Türkiye İstatistik Kurumu gibi farklı veri kaynaklarından toplanan veriler arasındaki tutarsızlıklar tarafımızca uyumlaştırılmaya çalışılmıştır. Sosyal hesaplar matrisinde katma değer bloğunun, özel kesim vergi ödemelerinin, kamu tarafindan yapılan transferlerin, özel kesim ve kamu kesimi tasarruflarının bulunmasında TÜIKK tarafindan yayınlanan Kurumsal Sektör Hesapları tablosu önemli bir veri kaynağı olarak kullanılmıştır.

2012 yll Türkiye için iki bölgeli sosyal hesaplar matrisi Tablo 11'de gösterilmektedir. Çalışmada uygulanan simülasyonlar 2016 yllı üzerinden 
gerçekleşeceğinden 2012 yılı Türkiye sosyal hesaplar matrisi ülkenin yıllık ortalama büyüme hızı çerçevesinde revize edilerek 2016 y1lı için ortaya konulmuştur. 2016 y1lı için yapılan güncellemede yine Yeldan vd. (2012) tarafindan oluşturulan yapı korunmuştur. Güncelleme yapılırken Kalkınma Bakanlı̆̆1 tarafindan yayınlanan, 2017 Y1lı Programı'nda yer alan, ekonominin genel dengesi büyüklükleri tablonun revize edilmesinde referans olarak kullanılmıştır. 
Tablo 11. 2012 Ylı Türkiye İki Bölgeli Sosyal Hesaplar Matrisi (Cari Fiyatlarla)

\begin{tabular}{|c|c|c|c|c|c|c|c|c|c|c|c|c|c|c|c|}
\hline 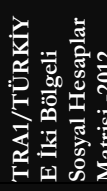 & & & 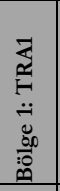 & & & 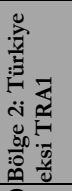 & & & & 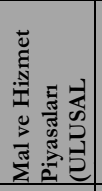 & \begin{tabular}{|c|}
$\frac{\pi}{\pi}$ \\
$\frac{\pi}{4}$ \\
\end{tabular} & & 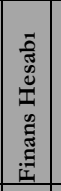 & 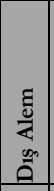 & $\begin{array}{l}\varepsilon \\
\frac{5}{0} \\
0 \\
0 \\
\end{array}$ \\
\hline & & & 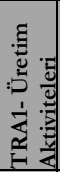 & 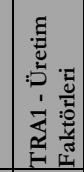 & & 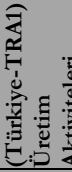 & & 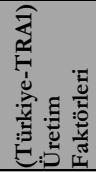 & & & & & & & \\
\hline & & & $\begin{array}{r}\xi \\
\stackrel{5}{\pi} \\
\stackrel{5}{\pi} \\
\end{array}$ & 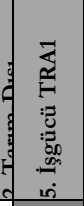 & 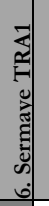 & 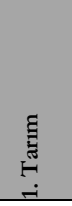 & 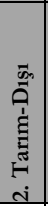 & 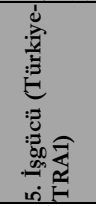 & 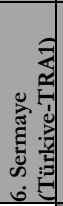 & 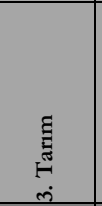 & 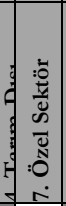 & 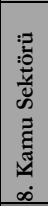 & 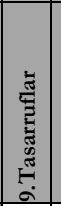 & 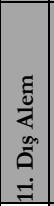 & \\
\hline 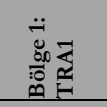 & 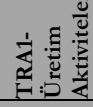 & 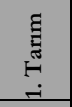 & & 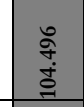 & $\begin{array}{l}\text { a } \\
\text { ते } \\
\text { ते } \\
\text { à }\end{array}$ & & & & & 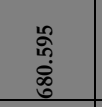 & & 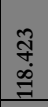 & & & $\begin{array}{l}2 \\
2 \\
\hat{0} \\
0 \\
\cdots\end{array}$ \\
\hline & & 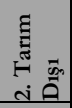 & & 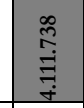 & 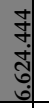 & & & & & & & 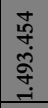 & & & 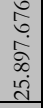 \\
\hline & 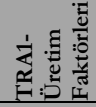 & 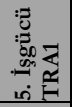 & & & & & & & & & $\begin{array}{l}\text { हे } \\
\dot{े} \\
\text { ळे }\end{array}$ & 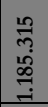 & & & 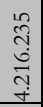 \\
\hline & & 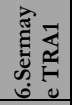 & & & & & & & & & 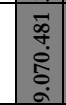 & 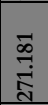 & & & 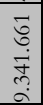 \\
\hline 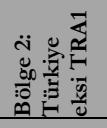 & 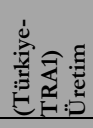 & 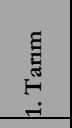 & & & & & & 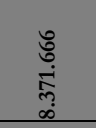 & 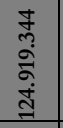 & 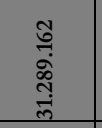 & & 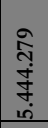 & & & $\begin{array}{l}\hat{\vec{a}} \\
\overrightarrow{2} \\
\overrightarrow{\vec{v}} \\
\vec{v} \\
\vec{v}\end{array}$ \\
\hline & & 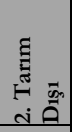 & & & & & & 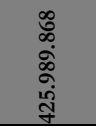 & $\begin{array}{l}\stackrel{2}{0} \\
\stackrel{3}{\infty} \\
\infty \\
0 \\
0 \\
\infty \\
\infty\end{array}$ & 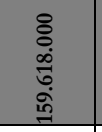 & & 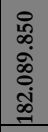 & & & $\begin{array}{c}n \\
0 \\
0 \\
\tilde{y} \\
10 \\
\infty \\
\infty \\
i \\
i\end{array}$ \\
\hline & 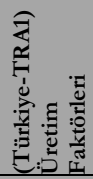 & 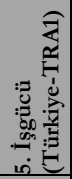 & & & & & & & & & 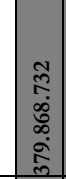 & 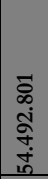 & & & 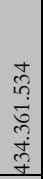 \\
\hline & & 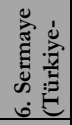 & & & & & & & & & 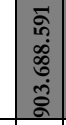 & 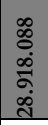 & & & 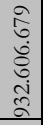 \\
\hline 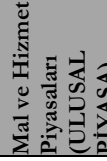 & & 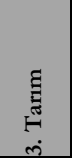 & $\frac{\widetilde{2}}{\dot{d}}$ & & & 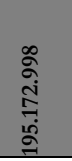 & & & & & & & & 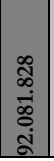 & $\begin{array}{l}\overrightarrow{0} \\
\stackrel{\vec{d}}{\mathrm{~T}} \\
\vec{I}\end{array}$ \\
\hline
\end{tabular}




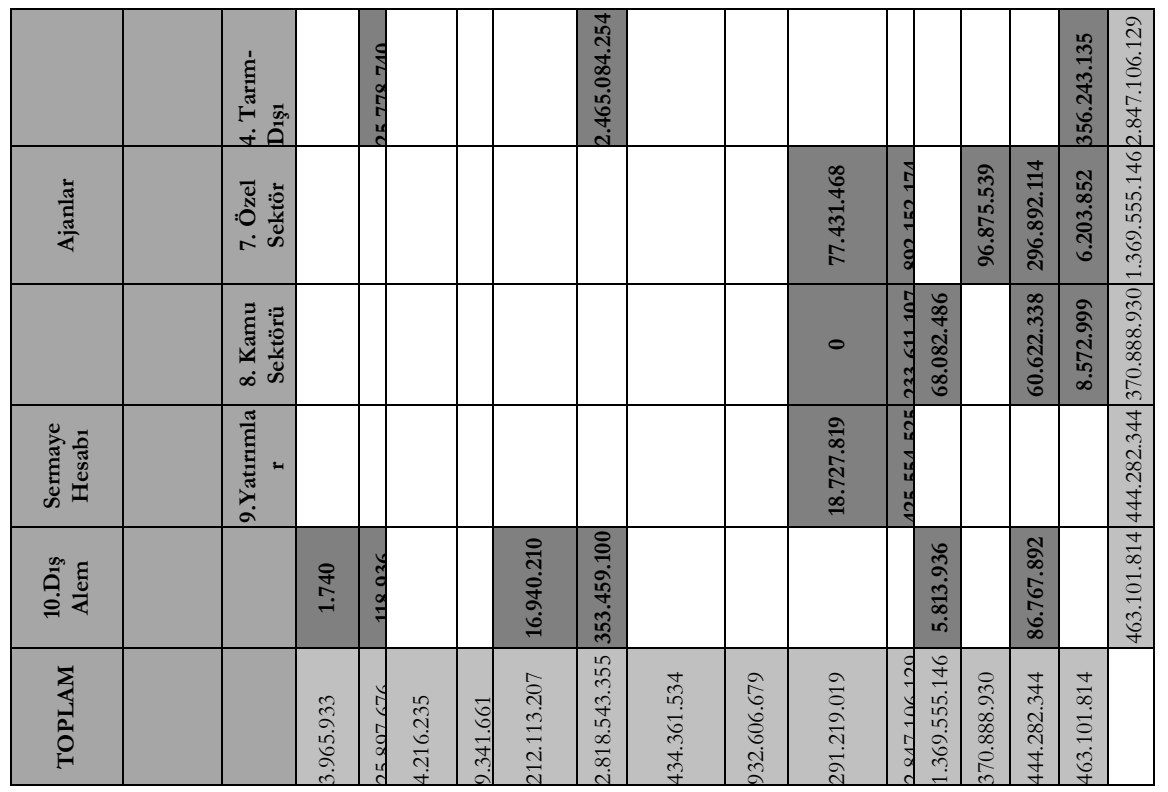

Kaynak: Yazar tarafindan oluşturulmuştur.

Tablo 12. 2017 Y11 Programı Ekonominin Genel Dengesi ${ }^{4}$

\begin{tabular}{|c|c|c|c|c|c|c|}
\hline & 2015 & $2016(1)$ & $2017(2)$ & 2015 & $2016(1)$ & $2017(2)$ \\
\hline & \multicolumn{3}{|c|}{ (Cari fiyatlarla, Milyon TL) } & \multicolumn{3}{|c|}{$\begin{array}{l}\text { (GSYH İçindeki Paylar, } \\
\text { Yüzde) }\end{array}$} \\
\hline Toplam Tüketim & 1649797 & 1839316 & 2031612 & 84,5 & 85,5 & 84,5 \\
\hline Kamu & 237107 & 285741 & 306444 & 12,1 & 13,3 & 12,7 \\
\hline Özel & 1412690 & 1553574 & 1725168 & 72,3 & 72,3 & 71,8 \\
\hline Toplam Yatırım & 359074 & 382361 & 453114 & 18,4 & 17,8 & 18,8 \\
\hline Kamu & 97418 & 105424 & 122071 & 5,0 & 4,9 & 5,1 \\
\hline Özel & 261656 & 276937 & 331044 & 13,4 & 12,9 & 13,8 \\
\hline $\begin{array}{l}\text { Sabit Sermaye } \\
\text { Yatırımı }\end{array}$ & 404107 & 440749 & 497133 & 20,7 & 20,5 & 20,7 \\
\hline Kamu & 95271 & 104499 & 122304 & 4,9 & 4,9 & 5,1 \\
\hline Özel & 308835 & 336249 & 374829 & 15,8 & 15,7 & 15,6 \\
\hline Stok Değişmesi & -45033 & -58388 & -44019 & $-2,3$ & $-2,7$ & $-1,8$ \\
\hline Kamu & 2146 & 925 & -234 & 0,1 & 0,0 & 0,0 \\
\hline Özel & -47179 & -59313 & -43785 & $-2,4$ & $-2,8$ & $-1,8$ \\
\hline $\begin{array}{l}\text { Toplam Yurtiçi } \\
\text { Talep }\end{array}$ & 2008871 & 2221676 & 2484726 & 102,9 & 103,4 & 103,4 \\
\hline $\begin{array}{l}\text { Net Mal ve } \\
\text { Hizmet İhracat1 }\end{array}$ & -56232 & -73555 & -80618 & $-2,9$ & $-3,4$ & $-3,4$ \\
\hline $\begin{array}{l}\text { Mal ve Hizmet } \\
\text { İhracat1 }\end{array}$ & 545978 & 565156 & 663852 & 28,0 & 26,3 & 27,6 \\
\hline $\begin{array}{l}\text { Mal ve Hizmet } \\
\text { İthalatı }\end{array}$ & 602210 & 638711 & 744470 & 30,8 & 29,7 & 31,0 \\
\hline
\end{tabular}

\footnotetext{
${ }^{4} \mathrm{Bu}$ çalışma hazırlandığında yayınlanan en güncel tablo bu olduğundan sosyal hesaplar matrisinin oluşturulmasında GSYH değeri olarak bu tablo referans alınmıştır.
} 


\begin{tabular}{|c|c|c|c|c|c|c|}
\hline $\begin{array}{l}\text { Gayrisafi Yurtiçi } \\
\text { Hasıla }\end{array}$ & 1952638 & 2148121 & 2404108 & 100,0 & 100,0 & 100,0 \\
\hline Net Faktör Gelirleri & -26431 & -24688 & -28201 & $-1,4$ & $-1,1$ & $-1,2$ \\
\hline $\begin{array}{l}\text { Net Diş Alem Cari } \\
\text { Transferleri }\end{array}$ & 3582 & 6173 & 6173 & 0,2 & 0,2 & 0,3 \\
\hline $\begin{array}{l}\text { Gayrisafi Milli } \\
\text { Harcanabilir Gelir }\end{array}$ & 1929789 & 2128279 & 2382080 & 98,8 & 99,1 & 99,1 \\
\hline $\begin{array}{l}\text { Kamu Harcanabilir } \\
\text { Geliri }\end{array}$ & 322421 & 343747 & 371093 & 16,5 & 16,0 & 15,4 \\
\hline Kamu Tüketimi & 237107 & 285741 & 306444 & 12,1 & 13,3 & 12,7 \\
\hline Kamu Tasarrufu & 85314 & 58006 & 64649 & 4,4 & 2,7 & 2,7 \\
\hline Kamu Yatırımı & 97418 & 105424 & 122071 & 5,0 & 4,9 & 5,1 \\
\hline $\begin{array}{l}\text { Kamu Tasarruf- } \\
\text { Yatırım Fark1 }\end{array}$ & -12104 & -47418 & -57421 & $-0,6$ & $-2,2$ & $-2,4$ \\
\hline $\begin{array}{l}\text { Özel Harcanabilir } \\
\text { Gelir }\end{array}$ & 1607368 & 1784532 & 2010987 & 82,3 & 83,1 & 83,6 \\
\hline Özel Tüketimi & 1412690 & 1553574 & 1725168 & 72,3 & 72,3 & 71,8 \\
\hline Özel Tasarrufu & 194679 & 230958 & 285818 & 10,0 & 10,8 & 11,9 \\
\hline Özel Yatırımı & 261656 & 276937 & 331044 & 13,4 & 12,9 & 13,8 \\
\hline $\begin{array}{l}\text { Özel Tasarruf- } \\
\text { Yatırım Fark1 }\end{array}$ & -66978 & -45979 & -45225 & $-3,4$ & $-2,1$ & $-1,9$ \\
\hline $\begin{array}{l}\text { Toplam Yurtiçi } \\
\text { Tasarruflar }\end{array}$ & 279993 & 288964 & 350468 & 14,3 & 13,5 & 14,6 \\
\hline
\end{tabular}

Kaynak: Kalkınma Bakanlığ1

Yillik programın esas alınmasının ardından oluşturulan sosyal hesaplar matrisi değerleri ve programda yer alan gerçek değerler aşağıda yer almaktadır.

Tablo 13. Sosyal Hesaplar Matrisi Doğrulama Değerleri

\begin{tabular}{|l|l|l|l|}
\hline & $\begin{array}{l}\text { 2017 Y1lık } \\
\text { Program (milyon } \\
\text { TL) }\end{array}$ & $\begin{array}{l}\text { 2016 SHM } \\
\text { Değeri (milyon } \\
\text { TL) }\end{array}$ & $\begin{array}{l}\text { Hata Pay1 } \\
\mathbf{( \% )}\end{array}$ \\
\hline GSYH & 2.148 .121 & 2.148 .121 & 0 \\
\hline Kamu Tüketimi & 285.741 & 285.741 & 0 \\
\hline Özel Tüketim & 1.553 .574 & 1.553 .574 & 0 \\
\hline Toplam Yatırım & 382.361 & 382.361 & 0 \\
\hline $\begin{array}{l}\text { Toplam Yurtiçi } \\
\text { Talep }\end{array}$ & 2.221 .676 & 2.221 .676 & 0 \\
\hline $\begin{array}{l}\text { Mal ve Hizmet } \\
\text { İhracatı }\end{array}$ & 565.156 & 565.146 & 0,00002 \\
\hline $\begin{array}{l}\text { Mal ve Hizmet } \\
\text { İthalatı }\end{array}$ & 638.711 & 638.701 & 0,00002 \\
\hline Kamu Tasarrufu & 58.006 & 58.006 & 0 \\
\hline Özel Tasarrufu & 230.958 & 235.986 & 0,02 \\
\hline
\end{tabular}

Kaynak: Yazar Tarafindan Oluşturulmuştur.

Tablo 13'te görüldüğü gibi, oluşturulan sosyal hesaplar matrisindeki değerler gerçek değerlerle uyumludur. Bunların yanında dış borç faiz ödemeleri için Dünya Bankası ve IMF verileri referans alınmıştır. 
Tablo 14. Diş Borç Faiz Ödemeleri, 2016

\begin{tabular}{|l|l|l|}
\hline & ABD Doları (bin dolar) & TL Değeri (bin TL) \\
\hline Özel Kesim & 8.513 .956 & 24.775 .609 \\
\hline Kamu Kesimi & 4.368 .128 & 12.711 .257 \\
\hline
\end{tabular}

Kaynak: Dünya Bankası ve IMF Verileri.

Bu hesaplamalarla elde edilen sosyal hesaplar matrisi Türkiye'de en güncel sosyal hesaplar matrisidir ve model bu matris veri alınarak kurgulanmıştır. Güncelleme sonucunda elde edilen 2016 yll iki bölgeli ve iki sektörlü sosyal hesaplar matrisi Ek 1'de sunulmaktadır.

İki bölgeli ve iki sektörlü yapıda oluşturulan sosyal hesaplar matrisinde ulusal ekonominin üretim, istihdam, gelirin dağılımı ve ihracat faaliyetleri bölgesel olarak kurgulanmaktadır. Modele ait denklem, değişken ve parametre listesi sirasiyla Ek 2., Ek 3. ve Ek 4.'te sunulmaktadır.

\subsection{Hesaplanabilir Genel Denge Modelinin Yapısı}

Model sosyal hesaplar matrisine paralel olarak üretim faaliyetleri ile mal ve hizmet hareketleri iki sektör altında, üretim faktörleri de emek ve sermaye olacak şekilde kurgulanmaktadır. Ek 2'de sunulan cebirsel denkliklerde i ve j endeksleri sosyal hesaplar matrisinin kapsadığı iki sektör olan tarım ve tarım dış1 sektörleri göstermektedir. $r$ endeksi bölgeyi (region), ry Bölge1’i ve rz Bölge 2'yi göstermektedir.

Uluslararası ticaret açısından küçük ülke varsayımı kabul edilmiştir. Yani analizin yapıldığı ekonomideki dış ticaret hadleri söz konusu ekonomideki içsel değişimlerden etkilenmemekte, ticareti yapılan malların fiyatları dünya piyasalarında dışsal olarak belirlenmektedir. Modelde farklı ülkelerde aynı isimle üretilen mallar arasında eksik ikame olduğunu varsayan ve büyük ölçüde bölgesel hesaplanabilir genel denge modellerinde kullanilan Armington varsayımı kullanılmışır. Bu varsayıma göre ithal edilen mallar ile yurtiçinde üretilen mallar arasında ikame söz konusu değildir. Bölge 1 ve Bölge 2'nin ürettiği katma değer ulusal düzeyde toplulaştırlmakta ve toplam ithalat ile birleştirilerek ulusal toplam arz elde edilmektedir. Bu varsayımın cebirsel ifadesi (1) nolu denklikte gösterilmektedir.

$$
C C_{i r}=A_{c i r}\left[\beta_{c i r} M_{i r}^{-\rho c i r}+\left(1-\beta_{c i r}\right) D C_{i r}^{-\rho c i r}\right] \frac{1}{\rho c i r}
$$

(1) nolu cebirsel gösterimde CCir bileşik ürün düzeyini, Acir Armington fonksiyonu üretkenlik katsayısını, $\beta$ cir toplam bileşik ürün içinde ithalatın payını, DCir yurt içi üretim miktarını ve Mir ithalatı göstermektedir.

$$
\sigma=\frac{1}{1-\rho}
$$


ise ithal edilen ve yurtiçinde üretilen mallar arasındaki ikame derecesini yani Armington esnekliğini göstermektedir. Çalışmada iki bölgeli bir yap1 kurgulandığından toplam arz miktarını DCy, DCz ve M oluşturmaktadır.

İthal edilen malların fiyatları, ihraç edilen malların fiyatları, karma mal fiyatı, toplam çıktı fiyatı ve katma değer fiyatı kurgulanan modelde yer alan fiyat denklikleridir. Bileşik mal sepetinin yani karma malın fiyatı, yurtiçi malların fiyatı ve ithalat fiyatına satış vergilerinin eklenmesi ile hesaplanmaktadır.

$$
P C_{i}=\left[P_{i}^{D}\left(\frac{D C_{i}}{C C_{i}}\right)+P_{i}^{M}\left(\frac{M_{i}}{C C_{i}}\right)\right] \cdot\left[1+\text { saltax }_{i}\right]
$$

İthalat fiyatı ithal edilen mallar için yurtiçi kullanıcılar tarafından ödenen fiyattır.

$$
P_{i}^{M}=P_{i}^{W M} \cdot \varepsilon\left(1+t m_{i}\right)
$$

İhracat fiyatı ise yurtiçi üreticilerin mallarını ihraç piyasasına sattıklarında elde ettikleri fiyattır.

$$
P_{i, r}^{E}=P_{i, r}^{W E} \cdot \varepsilon\left(1-t x_{i, r}\right)
$$

İhracat fiyatı ile ithalat fiyatı arasındaki temel farklılık verginin yurtiçi üreticinin elde ettiği fiyatı azaltmasıdır.

Yurtiçi üretim ve ithal edilen mal bileşimi CES (Constant Elasticity of Substitution- Sabit İkame Esnekliği) fonksiyonu ile ifade edilmektedir. Bölgesel toplam ürün arzı ihracat piyasasına sunulan ve yurtiçi piyasaya sunulan malların toplamından oluşmaktadır, bu durum CET (Constant Elasticity of Transformation) fonksiyonu ile gösterilmektedir. Mal akışş şeması Şekil 1'de gösterilmektedir.

Şekil 1. Pazarlanan Mal Akış Şeması, Lofgren vd.(2002), s. 12.

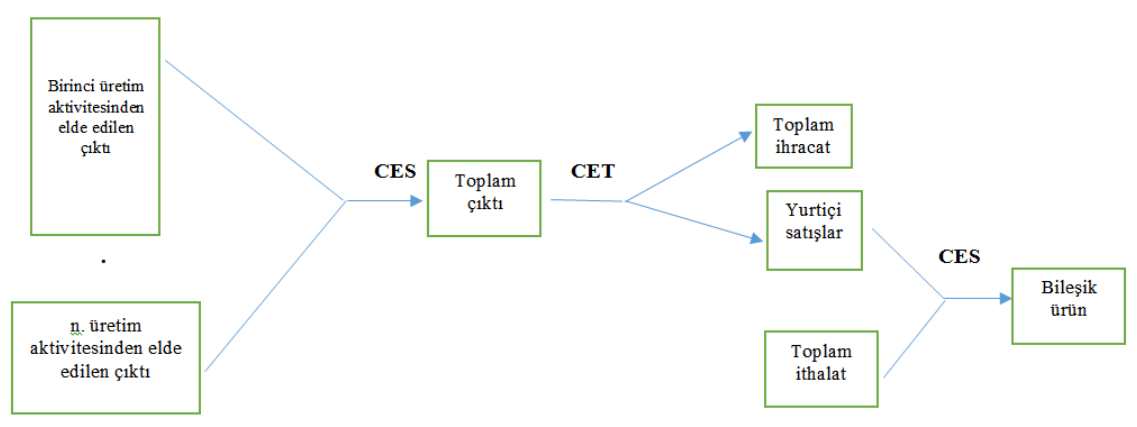


İthalatın modellenmesinde Armington varsayımı kullanılırken ihracatın modellenmesinde sabit dönüşüm fonksiyonu kullanılmıştır. Dolayısıyla bölgesel mal üretimi (XSi,r) bu fonksiyonla ifade edilmektedir. Sabit dönüşüm esnekliği fonksiyonu cebirsel haliyle

$$
X S_{i, r}=A_{t i r}\left[\beta_{t i r} E_{i r}^{\rho t i r}+\left(1-\beta_{t i r}\right) D C_{i r}^{\rho t i r}\right]^{1} \frac{1}{\rho t i r}
$$

şeklinde gösterilmektedir. Burada Atir sabit esneklik fonksiyonu üretkenlik katsayısını, ßtir yurtiçi toplam üretim içerisinde ihracatın payını; @tir ise dönüşüm esnekliği parametresini göstermektedir.

Modelde Bölge 1 ve Bölge 2'de ki toplam sermaye stokunun toplamı bölgesel sermaye talebine eşittir.

$$
\sum_{i} K_{i, r}=K S U P P_{r}
$$

İşgücü piyasasında denge, toplam işgücü arzından her bir bölgedeki işgücü talebinin çıkarılmasıyla elde edilen işsizlik oranı çerçevesinde ele alınmaktadır.

$$
U N E M P_{r}=L S U P_{R}-\sum_{i} L D_{i, r}
$$

Buradan UNEMPr, bölgesel işsizlik düzeyini, LSUPr bölgesel işgücü arzını ve LDir bölgesel, sektörler itibariyle işgücü talebini göstermektedir.

Modelde gelir bloğu özel kesim geliri ve kamu gelirinden oluşmaktadır. Özel kesim geliri, Bölge 1 ve Bölge 2'de istihdam edilen işgücüne yapılan ödemeler, kurumlar vergisi çıkarıldıktan sonra bölgesel düzeyde elde edilen karlar, devletten hanehalkına yapılan transferler, dış alemden gelen faktör gelirleri, özel kesime yapılan iç borç faiz ödemeleri toplamından özel kesim dış borç faiz ödemelerinin düşülmesi ile hesaplanmaktadır.

$Y=\sum_{i}\left(\left(W_{r} \cdot\right.\right.$ WFDIST $_{i r} L D_{i r}+\left(1-\right.$ corprtax $\left.\left.\left._{r}\right) \cdot R K_{r} \cdot \operatorname{RKDIST}_{i, r} \cdot K_{i, r}\right)\right)+$ GOVTRANS + INTDOM * GDOMDEBT + NPFI- INTFORP * PFORDEBT

Denklem (9)'da Wr bölgesel ücret düzeyini, WFDISTir bölgesel sektörler itibariyle ücret farklılaşma katsayısını, GOVTRANS kamu transfer harcamalarını, INTDOM yurtiçi faiz oranını, GDOMDEBT kamu kesimi iç borç stokunu, NPFI yurt dışı net faktör gelirini, INTFORP özel kesim dış borç faiz yükünü, PFORDEBT özel kesim dış borç stokunu, RKr bölgesel kar oranını, RKDISTir bölgesel sektörler itibariyle kâr oranı farklılaşma katsayılarını göstermektedir. 
Modelde devlet tüm gelirini vergilerden elde etmektedir. Buna göre kamu geliri, üretim vergisi, satış vergisi, gümrük vergisi, sosyal güvenlik vergisi, kurumlar vergisi, gelir vergisi ve ihracat vergisinden oluşmaktadir.

$$
\begin{gathered}
\text { GREV }=\text { TOTPROTAX }+ \text { TOTSALTAX + TARIFF + TOTSSTAX + } \\
\text { TOTCORPTAX + TOTHHTAX + EXTAX }
\end{gathered}
$$

Burada TOTPROTAX üretim vergisini, TOTSALTAX satış vergisini, TARIFF gümrük vergisini, TOTSSTAX sosyal güvenlik vergisini, TOTCORPTAX kurumlar vergisini, TOTHHTAX gelir vergisini ve EXTAX ihracat vergisini göstermektedir.

Özel kesimin gelirinin sabit bir oranını tasarruf ettiği varsayılmaktadır. Tasarruftan geriye kalan gelir tüketim harcaması olarak sektörler arasında dağıtılmaktadır. Buna göre özel kesim tüketimi ve özel kesim tasarrufu cebirsel ifadesiyle

$$
\begin{aligned}
& C D_{i}=\frac{\text { cles }_{i} \cdot(1-m p s) \cdot Y H H \cdot(1-\text { htax })}{P C_{i}} \\
& \text { PRSAV }=\text { mps } \cdot Y H H \cdot(1-\text { htax })
\end{aligned}
$$

şeklinde gösterilmektedir. Burada CDi özel kesim tüketimini, PRSAV özel kesim tasarrufunu; mps özel kesim marjinal tasarruf eğilimini, htax hanehalk1 vergisinin toplam hanehalkı gelirine oranını; clesi özel tüketim amacıyla kullanılan ürünler içerisinde sektörel ürünlerin değer olarak payını ve PCi bileşik ürün fiyatını göstermektedir.

Özel tüketimde olduğu gibi diğer nihai kullanım unsurları da modellenmiştir. Buna göre kamu tüketimi, özel yatırım ve kamu yatırımlarının sektörel dağılımı sırasıyla

$$
\begin{aligned}
& G D_{i}=\frac{\text { gles }_{i} \cdot G O V C O N}{P C_{i}} \\
& I D_{i}=\frac{\text { idles }_{i} \cdot P R I N V}{P C_{i}} \\
& G I D_{i}=\frac{\text { gidles }_{i} \cdot G I N V}{P C_{i}}
\end{aligned}
$$

denklemleri ile gösterilmektedir. Bu denklemlerde sırasıyla GDi, IDi ve GIDi sektörel ürünlerin kamu tüketimi, özel yatırım ve kamu yatırımı için 
kullanılan miktarlarını göstermektedir. glesi, idlesi ve gidlesi ise sırasıyla kamu tüketimi, özel yatırım ve kamu yatırımında sektörel ürünlerin payını göstermektedir.

Kamu tüketimi GSYH'nın sabit bir oranı olarak modellenmiştir. Buna göre kamu tüketimi

$$
G O V C O N=g c r \cdot G D P
$$

denklemi ile gösterilmektedir. Bu denklemde GOVCON toplam kamu tüketimini, gcr kamu tüketiminin GSYH içindeki payını ve GDP, GSYH'y1 göstermektedir.

Kamu yatırımıda kamu tüketiminde olduğu gibi GSYH'nın sabit bir oranı olarak modellenmiştir.

$$
G I N V=\operatorname{gir} . G D P
$$

Burada GINV toplam kamu yatırımını, gir, GSYH içinde kamu yatırımlarının payını göstermektedir.

Kamu kesimi tasarrufuna, kamu gelirinden kamu tüketim harcamalarının, kamu transfer harcamalarının, kamu kesimi iç ve dış borç faiz ödemelerinin çıkarılması ile ulaşılmaktadır.

$$
G S A V=G R E V-G O V C O N-G O V T R A N S-i r_{F G} \cdot \varepsilon \cdot G F D-i r_{D O M} \cdot G D D
$$

Burada GREV toplam kamu gelirini, GOVTRANS kamu transferlerini, GOVCON toplam kamu tüketim harcamalarını, irFG ve irDOM kamu kesimi dış borç faiz oranı ve kamu kesimi iç borç faiz oranını göstermektedir. GFD ve GDD ise sırasıyla kamu kesimi dış borç stoku ve kamu kesimi iç borç stokuna karşl1k gelmektedir.

Mal piyasası dengesi, ödemeler dengesi ve toplam tasarruf toplam yatırım dengesinin sağlanmasıyla genel ekonomi dengesi sağlanmış olacaktır. Mal piyasası dengesine göre toplam mal ve hizmet arzı toplam mal ve hizmet talebine eşit olmalıdır. Sosyal hesaplar matrisinde satır ve sütunların denk olması gerektiğinden mal piyasası dengesi de sosyal hesaplar matrisinde mal ve hizmetler satırr ile sütununun dengeye gelmesini ifade etmektedir. Buna göre mal piyasası dengesi

$$
C C_{i}=I N T_{i}+C D_{i}+G D_{i}+I D_{i}+G I D_{i}
$$

denklemi ile ifade edilmektedir. Burada CCi toplam bileşik ürünü, INTi toplam ara girdi kullanımını göstermektedir. 
Ödemeler dengesi de yine sosyal hesaplar matrisi kurgusuna göre diş alem satırı ile sütununun denk olması anlamına gelmektedir. Ödemeler dengesi cebirsel ifadeyle

$$
\begin{aligned}
& \sum_{i} P_{i}^{W M} M_{i}+i r_{F P} \cdot P F D+i r_{F G} \cdot G F D+\frac{E E R P t r R O W}{\varepsilon}= \\
& \sum_{i} P_{i}^{W E} E_{i}+\text { ROWtrEE }+ \text { ROWtrHH }+ \text { FSAV }
\end{aligned}
$$

şeklinde gösterilmektedir. Burada ROWtrEE firmaların dış alemden elde ettiği döviz gelirini, ROWtrHH işçi gelirlerini ve EERPtrROW firmaların yurtdısına yaptıkları kar transferlerini göstermektedir.

Son olarak tasarruf yatırım denkliğinin cebirsel ifadesi

$$
P R S A V+G S A V+\varepsilon \cdot F S A V=P R I N V+G I N V
$$

şeklinde gösterilmektedir. Burada PRSAV özel kesim tasarrufunu, GSAV kamu kesimi tasarrufunu, FSAV dış tasarrufu, PRINV özel kesim yatırımını ve GINV kamu kesimi yatırımını göstermektedir.

\section{Bölgesel Politika Uygulamaları}

Bu bölümde, önceki bölümde tanımlanan iki bölgeli hesaplanabilir genel denge modeli kullanılarak analizi yapılan alternatif politika varsayımları açıklanmaktadır. Modelleme dönemi, bütün senaryolar için 2016-2023 yıllar1 olarak belirlenmiştir. Modelde iki farklı senaryo test edilmiştir. İlk senaryoda kamu yatırımlarındaki $\% 5$ lik ve özel yatırımlardaki $\% 3$ 'ük artışı bölge ekonomisi üzerindeki olası etkileri analiz edilmiştir. İkinci senaryoda yatırımlara ilave olarak toplam faktör verimliliğinde meydana gelecek bir artışı bölge ekonomisi üzerindeki etkileri gösterilmeye çalışlmıştır. Model GAMS programı ile çözülmüştür.

\subsection{Baz Durum}

Herhangi bir şokun olmadığ1 durum baz durum olarak değerlendirilmektedir. Yapılan varsayımlar ile model içsel olarak yıllar bazında ileriye doğru eş anlı denklemler aracıllğıyla çözülmektedir. 


\section{Grafik 1. Baz durum, Yatırım Oranları (\%)}

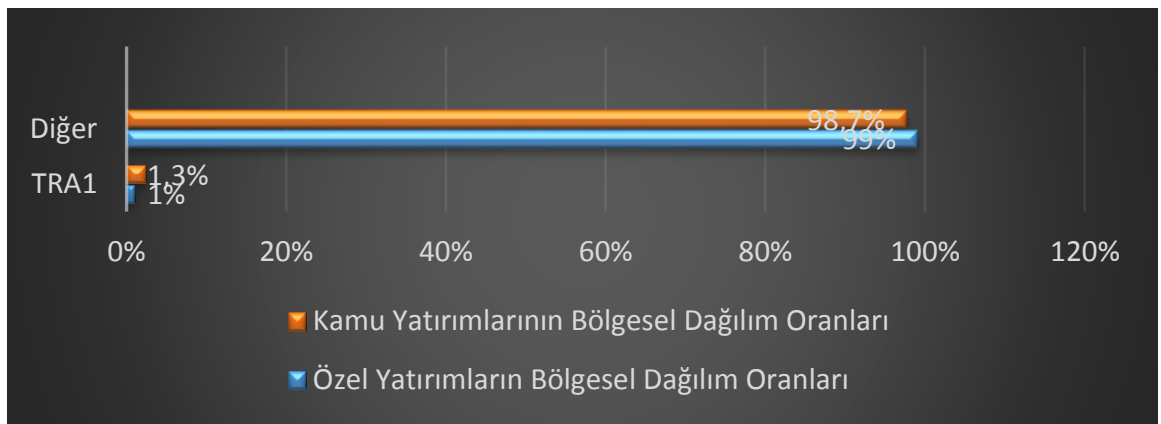

TRA1 bölgesinin kamu yatırımlarından aldığ1 pay Kalkınma Bakanlı̆̆1 tarafından yayınlanan Kamu Yatırım Tahsislerinin Illere Göre Dağılımı tablosuna göre 2015 yılında \%1,3’ tür, özel kesim yatırımları ise \%1 seviyesindedir. 2016 yılına ait rakamlar henüz yayınlanmadı̆̆ından bu rakamlar kullanılmaktadır.

Tarım ve tarım dişı sektörlerde toplam faktör verimliliğinin daha önce Yeldan vd. (2013) tarafından varsayıldığı gibi olduğu kabul edilmiştir. Bu çalışmaya göre toplam faktör verimliliği yüksek gelirli bölgede tarım sektöründe \%0,5; tarım dış1 sektörlerde \%1,5’tir. Yoksul bölgede tarım sektöründe toplam faktör verimliliği $\% 0,0$; tarım dışında $\% 0,1$ 'dir. Uygulanacak varsayımlara göre bu verimlilik değerleri değişebilir. Tarım ve tarım dışı sektörlerde toplam faktör verimliliğinin artırılmasına yol açan politika müdahalelerinin sonuçları ölçülebilir. Baz durum halinde ve yukarıdaki varsayımlar neticesinde kurgulanan modelin çözümü ile bölge ekonomisine yönelik sonuçlar aşağıdaki grafiklerde gösterilmektedir.

\section{Grafik 2. Baz Durum, Ortalama Ücret Düzeyi (TL)}

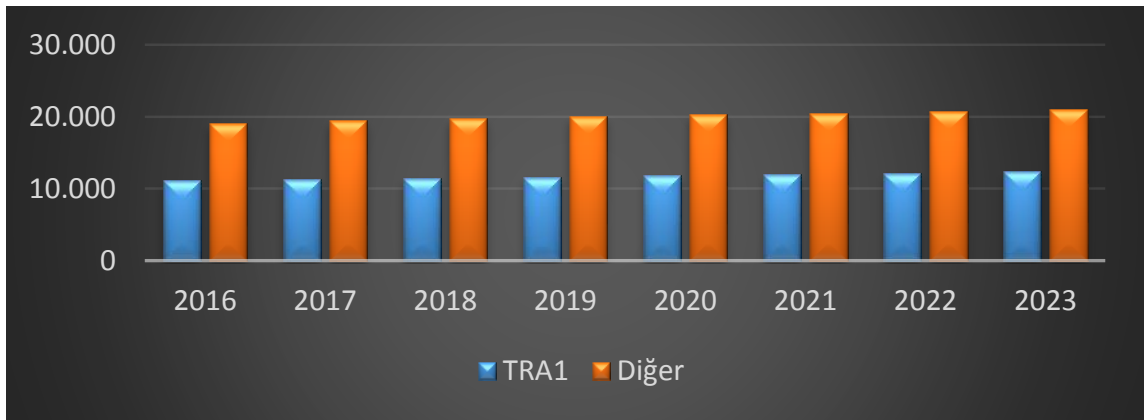

Ortalama ücret bakımından ise TRA1 bölgesinde 2016 y1lı reel 11.072 TL olan emek değerinin 2023 yilı itibariyle 12.380 TL olacağ1 ve 2016 y1lında 19.069 TL olan TRA1 dişındaki diğer bölgelerde emek değerinin 2023 yilında 21.040 TL’ye erişeceği beklenmektedir. TRA1 bölgesi ortalama emek ücreti 
ile Türkiye eksi TRA1 bölgesinin (diğer) ortalama emek ücreti oranının ise $\% 58$ civarında seyredeceği hesaplanmaktadır.

\section{Grafik 3. Baz Durum, Katma Değer (TL).}

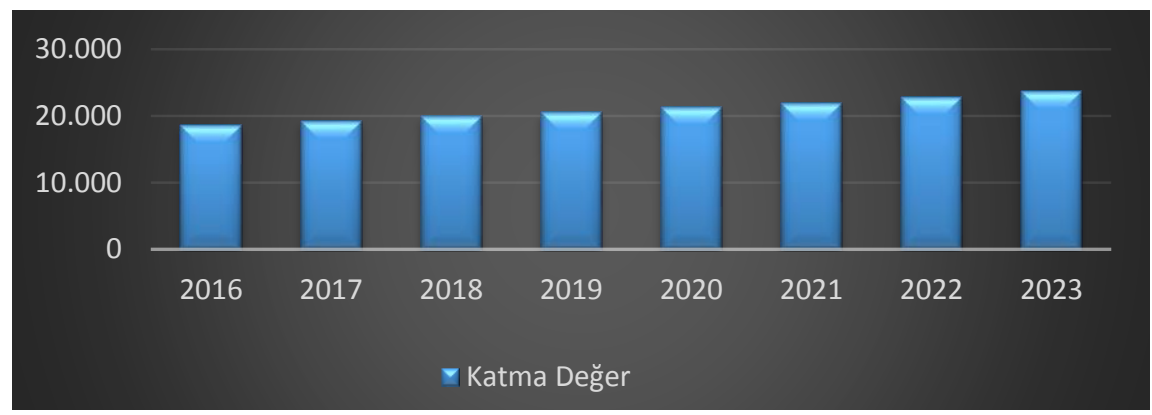

Bölgede iktisadi olarak herhangi bir değişikliğin olmadı̆̆ baz durumunda 2016 yllında 18.610 TL olan bölge katma değeri 2013 yllında 23.684 TL'ye ulaşmaktadır.

\section{Grafik 4. Baz Durum, TRA1 Düzey 2 İşgücü Talebi (bin kişi)}

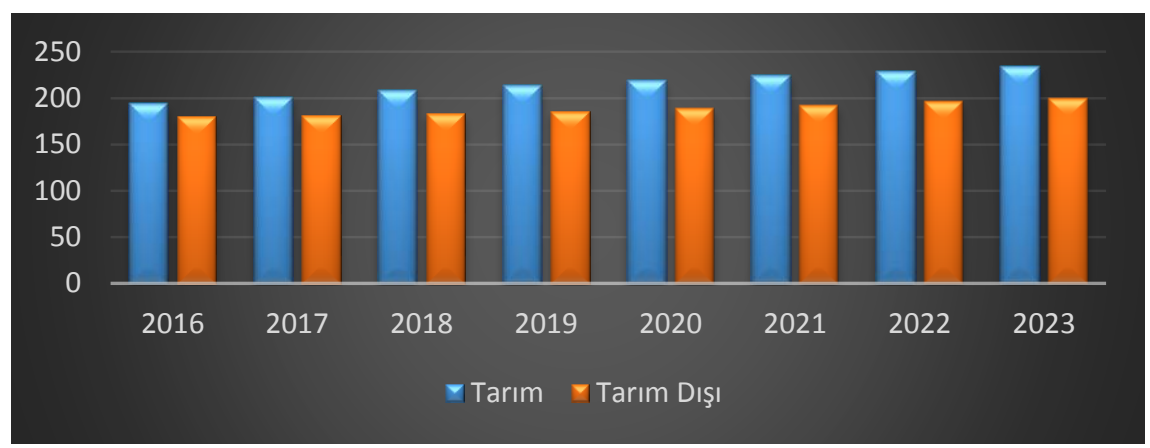

TÜİK verilerine göre 2015 yll Türkiye tarım sektörü istihdam oranı $\% 20,6$, sanayi sektörü istihdam oran1 $\% 27,2$ ve hizmetler sektörü istihdam oranı \%52,2'dir. TRA1 bölgesi için bu oranlar sirasıyla \%51,7, \%10,8 ve \%37,5’tir. Bölgenin istihdamında tarım sektörünün ağırlığ1 göze çarpmaktadır. Baz duruma göre tarım sektörünün 2017-2023 döneminde 33 bin kişi ilave istihdam oluşturulacağı hesaplanmıştır. Tarım dışı sektörlerde ise bu artış sadece 19 bin kişidir. Tarım sektöründeki istihdamın tarım dışı sektördeki istihdama oranının \%1,11'den \%1,17'ye artacağ hesaplanmıştır. Bu durum bölgede istihdam açısından dağılımın tarım lehine olacağını ve bölge ekonomisi açısından olumsuz sonuçlar ortaya çıkabileceğini göstermektedir. Çünkü tarım dışı sektörlerde istihdamın düşük olması bölgede işgücü gelirleri üzerinde olumsuz baskı oluşturacak ve bölgedeki göç eğilimini artıracaktır.

Hesaplanabilir genel denge modeli baz durum sonuçları toplu olarak EK 5'te yer almaktadir. 


\subsection{Senaryo 1: Yatırım Artış1}

Çalışmada iki farklı senaryo uygulaması ile bölge ekonomisi analiz edilmeye çalışılmaktadır. Bu amaçla senaryo 1 uygulamasında bölgeye yapılacak olan kamu kesimi ve özel kesim yatırımlarının, senaryo 2 uygulamasında ise bu yatırımların verimlilik artışları ile desteklenmesinin bölgeye etkisi araştırılmaktadır.

Baz durumda \%1,3 olan kamu yatırmmlarının ilk senaryoda \%5'e ve yine baz durumda \%1 olan özel kesim yatırımlarını \%3'e artırlması öngörülmektedir. Kamu kesimi tarafindan yapılan yatırımların özel kesim yatırımlarını tamamladığı söylenebilir. Örneğin, kamu kesimi tarafından yapılan ulaşım, iletişim ve eğitim gibi yatırımlar özel kesimin yatırım planlarını uygulamasını ve gerçekleştirmesini kolaylaşırıı. Bir diğer ifadeyle, artan kamu harcamaları ekonomik ve sosyal altyapıda iyileşmeye yol açacak, bunun sonucunda özel yatırımı teşvik edecek olan daha yüksek bir özel sermaye getiri oranı ortaya çıkacaktır. Bunun yanında kamu yatırımları sadece özel kesim tarafindan üretilen mal ve hizmetlere olan talebi artırmaz, aynı zamanda özel yatırımcıların gelecekteki kâr ve satış beklentilerini de etkiler.

\section{Grafik 5. Senaryo 1, Yatırım Oranları (\%)}

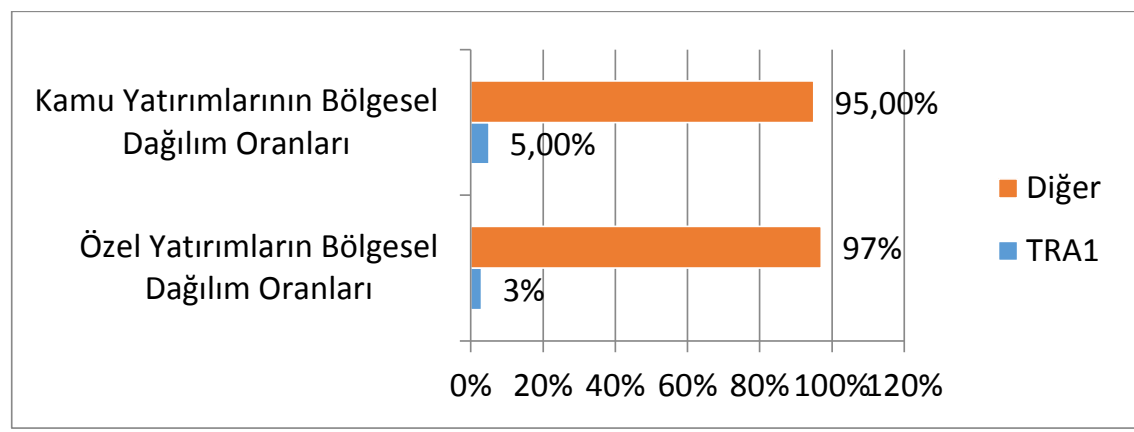

Yukarıdaki grafikte görüldüğü gibi TRA1 Düzey 2 Bölgesi’nin kamu yatırımlarından aldığı payın \%5’e ve özel kesim yatırımlarından aldığı payın \%3'e çıktığı varsayılmaktadır.

Tarımsal ve tarım dışı toplam faktör verimliliği baz durum ile aynıdır, senaryo 1'de sadece bölgenin kamu ve özel kesimden alacağı yatırım paylarının değiştĭgi varsayllmaktadır.

Yatırımlarla ilgili verilen şokun yani senaryo 1 sonucunda genel denge modelinin çözümüyle elde edilen sonuçlar aşağıdaki grafiklerde sunulmaktadır. 


\section{Grafik 6. Senaryo 1, Ortalama Ücret Düzeyi (TL)}

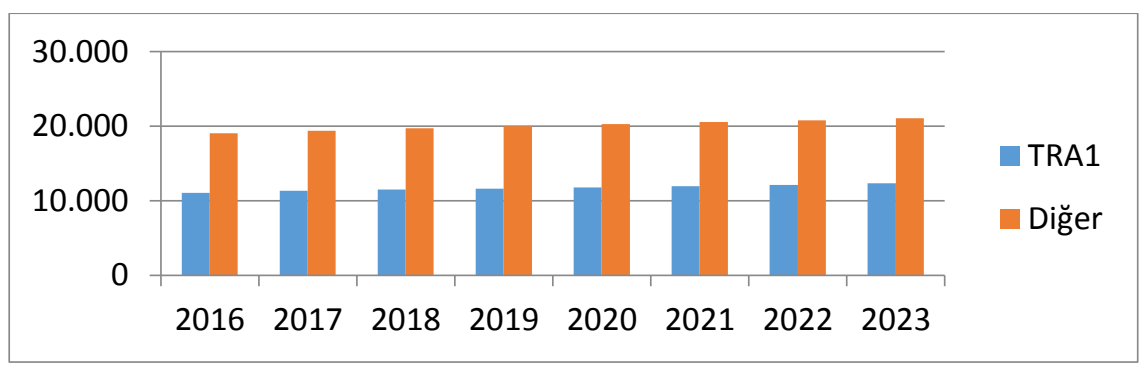

TRA1 bölgesinde ortalama ücret düzeyinin 11.072 TL'den 12.356 TL'ye yükseleceği hesaplanmıştır. Diğer bölgelerde ise ortalama ücret düzeyi 19.069 TL'den 21.183 TL'ye yükselecektir.

\section{Grafik 7. Senaryo 1, Katma Değer (TL)}

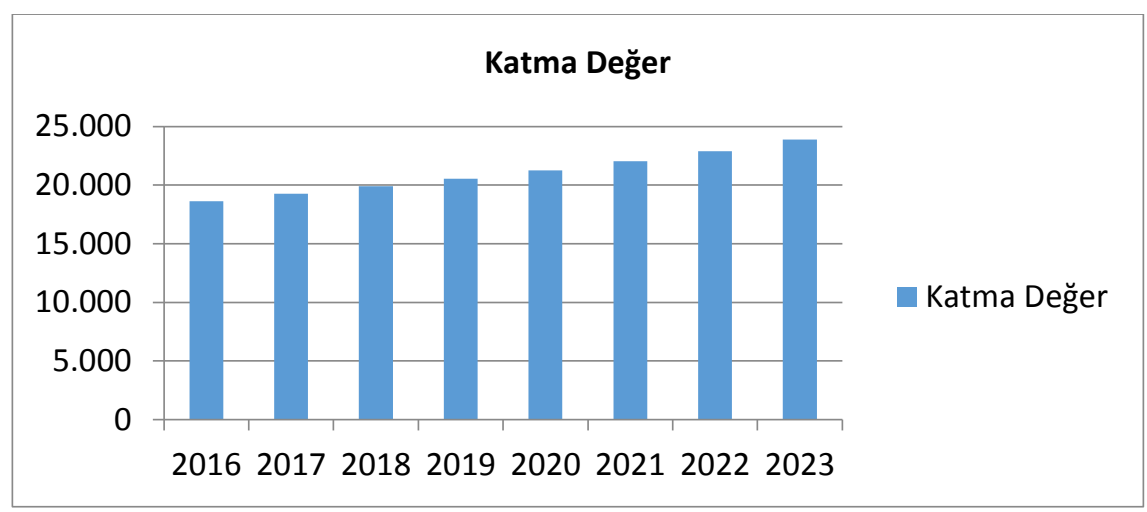

Yatırım tahsislerine yönelik varsayımların gerçekleşmesi halinde bölgenin katma değer düzeyi baz duruma göre artış gösterecektir.

\section{Grafik 8. Senaryo 1, TRA1 Düzey 2 İşgücü Talebi (bin kişi)}

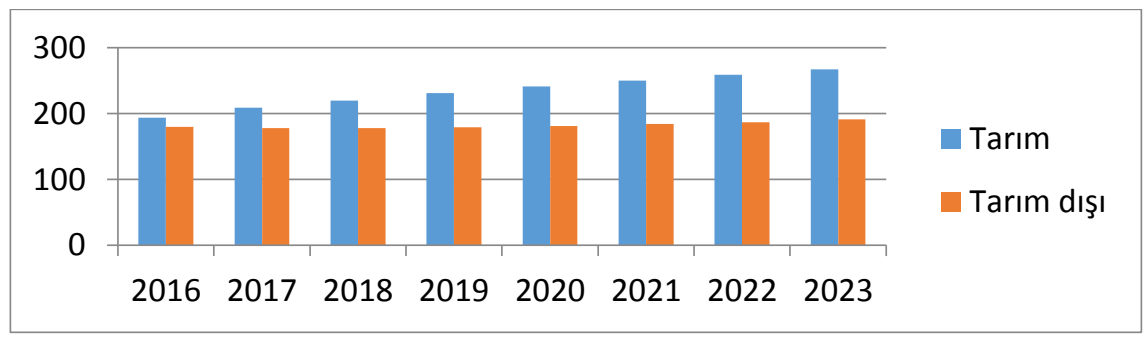

Bölge için oldukça önemli göstergelerden biri olan istihdam düzeyine yönelik sonuçlar Grafik 8'de gösterilmektedir. Buna göre bölgenin istihdam düzeyinde yavaş ta olsa bir artış öngörülmekte ve gelecek 7 yll içerisinde 
bölgenin tarımsal istihdamında 73 bin ve tarım dişı istihdamında 11 bin ilave istihdam oluşturması beklenmektedir.

Grafik 9. Senaryo 1, TRA1 Düzey 2 Bölgeiçi Tüketim (TL)

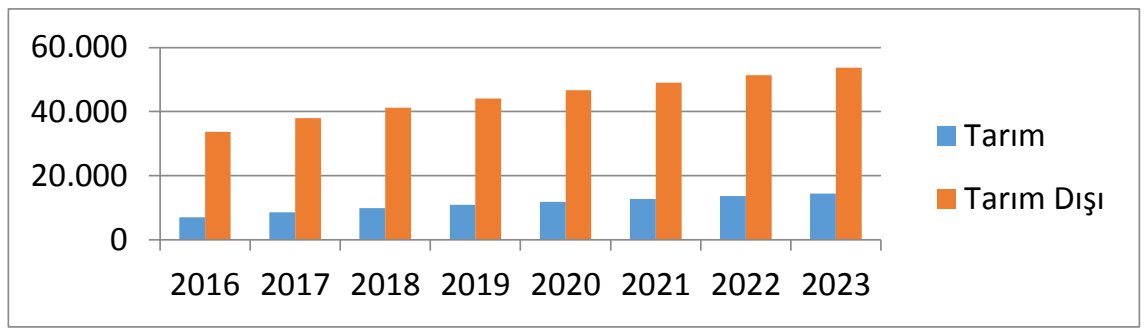

Senaryo 1 uygulaması sonucunda bölgeiçi tüketimde ortaya çıkacak değişimler Grafik 9'da gösterilmektedir.

Bölgeye yapılacak yatırım tahsislerinin değişmesi durumunda (Senaryo 1) model çözümü sonucu elde edilen hesaplanabilir genel denge modelinin sonuçları toplu olarak EK 6'da sunulmaktadır.

\subsection{Senaryo 2: Toplam Faktör Verimliliği Artış1}

Baz durumda bölgenin kamu yatırımlarından aldığı payın \%1,3 ve özel kesim yatırımlarından aldığ1 payın \%1 olduğu kabul edilmiştir. Senaryo 1'de sadece bu yatırım tahsisinin değiştiği toplam faktör verimliliğinde herhangi bir değişikliğin olmadığı varsayılmıştır. Senaryo 2 uygulamasında ise bu yatırım artışlarının yanında verimlilik artışının bölge ekonomisine etkisi analiz edilmeye çalışılacaktır.

Baz durum halinde bölgede tarım sektöründe toplam faktör verimliliğinin $\% 0,0$ ve tarım dışında \%0,1 olduğu varsayılmıştı. Senaryo 2'de yatırımların bölgede verimliliği, tarım sektöründe $\% 0,5$; tarım dişı sektörlerde ise $\% 0,7$ oranında geliştirileceği hipotez edilmektedir. TRA1 bölgesinde iller arasında önemli verimlilik farklarının olmadığı kabul edilmiştir. Bu varsayım da yine Yeldan vd. (2013) çalışması referans olarak alınmıştır.

Toplam faktör verimliliği ile ilgili verilen şokun yani senaryo 2 sonucunda genel denge modelinin çözümü ile elde edilen sonuçlar aşağıdaki grafiklerde verilmektedir. 


\section{Grafik 10. Senaryo 2, Ortalama Ücret Düzeyi (TL)}

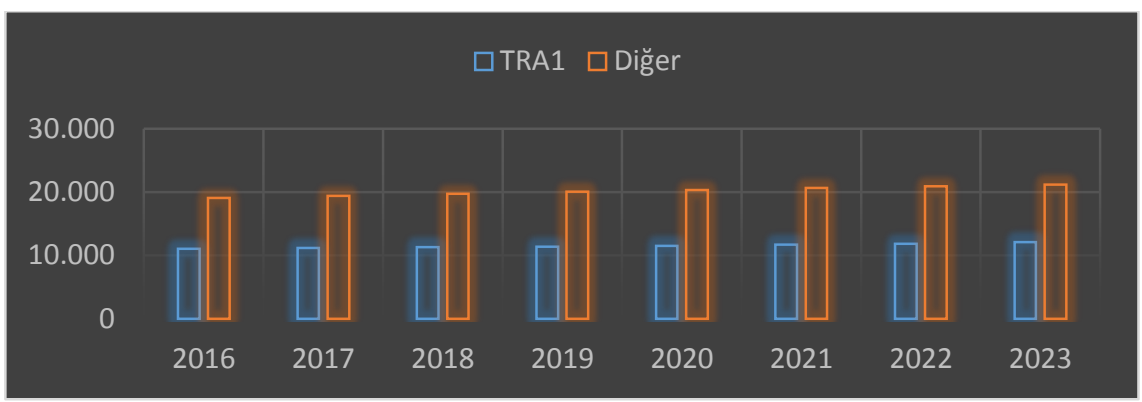

Senaryo 2 uygulamasiyla TRA1 bölgesinde ortalama ücret düzeyinin 11.072 TL'den 12.072'ye yükseleceği hesaplanmıştır. Senaryo 1 uygulanmasinda 2023 yilında ortalama ücret düzeyinin 12.356 TL'ye yükseleceği hesaplanmıştı. Diğer bölgelerde senaryo 2 uygulaması sonucu ortalama ücret düzeyi 19.069 TL'den 21.059 TL'ye yükselmiştir. Senaryo 1'de diğer bölgelerde ücret düzeyinin 2023 yllında 21.183 TL'ye yükseleceği hesaplanmıştı ve senaryo 1'de TRA1 bölgesi ortalama ücret düzeyi ile diğer bölgelerin ortalama ücret düzeyi oran1 $\% 58$ 'den $\% 59$ 'a artıyorken senaryo 2 'de bu oran \%58'den \%56'ya gerilemektedir. Verimlilik artısıyla ücret farkının giderek azalacağı hesaplanmaktadır

\section{Grafik 11. Senaryo 2, Katma Değer (TL)}

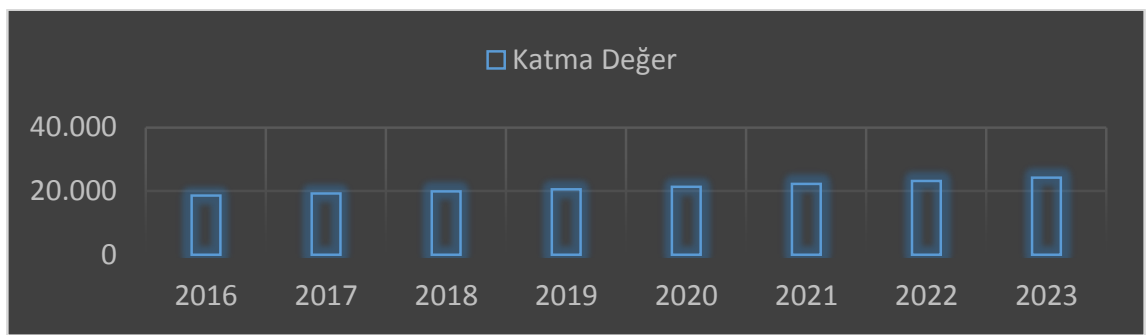

Toplam faktör verimliliğine yönelik varsayımların gerçekleşmesi halinde bölgenin katma değerinin 7 yıllık dönemde baz durumua göre giderek artacağ1 beklenmektedir. Katma değer artışında verimlilik yatırımlardan daha etkili olmaktadir.

Grafik 12. Senaryo 2, TRA1 Düzey 2 İşgücü Talebi (bin kişi)

\section{$\square$ Tarım $\square$ Tarım Dışı}


Bölgenin istihdam düzeyine yönelik sonuçlar Grafik 12'de gösterilmektedir. Buna göre bölgenin istihdam düzeyinde toplam faktör verimliliğinin artmasıyla iyimser bir gelişme ortaya çıktığı görülmektedir. $\mathrm{Bu}$ durumda varsayılan birinci modele göre tarımsal istihdamda azalma, buna karşın tarım dışı istihdam oranında artış ortaya çıkmaktadır.

\section{Grafik 13. Senaryo 2, TRA1 Düzey 2 Bölgeiçi Tüketim (TL)}

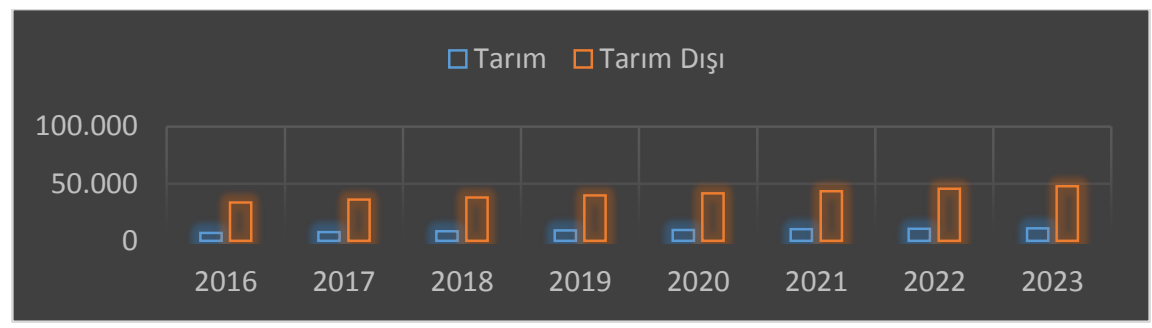

Senaryo 2'de bölgeiçi tüketimde ortaya çıacak değişiklikler Grafik 13'te gösterilmektedir. Senaryo 2'de bölgeiçi tarımsal tüketimin tarım dışı tüketime oran1 \%21'den \%23'e artarken, senaryo 1'de bu gelişim \%21'den \%27'ye artmaktadır. Bu durum bölgede tarım sektörünün önemini korumaya devam edeceğini göstermektedir. Ancak verimlilik artışıla tarımsal tüketim/ tarım dışı tüketim oranı azalacaktır. Yani tarım dışı ürünlere olan talep artacak, bu durum tarım dışı üretimin artmasına ve bölgede istihdam imkanlarının gelişmesine imkan verecektir, özellikle istihdamın tarım dış1 sektörlere kayması beklenebilir.

Toplam faktör verimliliğinin artması sonucunda (Senaryo 2) model çözümüyle elde edilen hesaplanabilir genel denge modelinin sonuçları EK 7'de sunulmaktadır.

\section{Sonuç}

Bölgesel kalkınma uzun bir süre merkezi hükümetin müdahalesi ve desteğiyle gerçekleştirilmeye çalışılmıştır. Fakat artık bölgesel kalkınma yerel, ulusal ve hatta uluslararası aktörlerin katılımıyla gerçekleştirilebilmektedir. $\mathrm{Bu}$ amaçla 2006 y1lından sonra tüm Düzey 2 Bölgeleri'nde Kalkınma Ajansları kurulmaya başlamıştır. Böylece bölgesel kalkınma pratiklerinin yaygın hale gelmesi ve hız kazanması beklenmektedir.

Ağıllkkl olarak fiziki sermaye birikiminin artırılması yerine, toplam faktör verimliliğini artıracak harcama ve yatırımların yapılmasının daha faydalı olacağı görüşünün yaygınlaştığı son dönemde bu çalışma bölgesel kalkınmada yatırım ve verimlilik ilişkisini araştırmaktadır.

Çalışmanın veri seti için oluşturulan SHM Türkiye için en güncel sosyal hesaplar matrisi olma özelliğini taşımaktadır ve bir Düzey 2 bölgesi için oluşturulan ilk matristir. Hesaplanabilir genel denge modelciliğinin ilk adımı 
veri setinin oluşturulması olduğundan bu aşamaların tümünü içermesi yönüyle çalışma hesaplanabilir genel denge modeli uygulamalarının bütüncül bir çerçeve içinde değerlendirilmesine imkân tanımaktadır. Hesaplanabilir genel denge modelleri kullanılarak güvenilir analizler gerçekleştirebilmek için farklı kurumlar tarafindan yayınlanan verilerin tutarlı bir şekilde bir araya getirilmesi gerekmektedir. Veri altyapisının tutarlı hale getirilmesiyle bu çalışmanın amacı olan ve ülkemizde ön plana çıkan bölgesel kalkınma sorunu için alternatif senaryoların çözümü mümkün olmaktadır.

Kurgulanan modele çalışmada öngörülen şokların verilmesinden önce baz durumunda bölgenin ekonomik olarak görünümü açıklanmıştır. Baz durumunda TRA1 bölgesinin kamu yatırımlarından aldığı payın \%1,3 ve özel yatırımlardan aldığı payın $\% 1$ olduğu durumda ve toplam faktör verimliliğinin bölge de tarım sektöründe $\% 0,0$ ve tarım dışında $\% 0,1$ olduğu varsayılmıştır.

İlk senaryo uygulaması bölgenin kamu yatırımlarından aldığı payın $\% 5$ ve özel yatırımlardan aldığı payın \%3 olacağını varsaymakta ve yatırımlarda meydana gelen artısıın bölge ekonomisine olan etkisini göstermektedir. Yatırımların artırılması sonucu ortalama ücret düzeyinde ortaya çıkacak artışın büyük kısmı hanehalkına yapılan maaş ödemelerinden oluşmaktadır. Bölgede katma değerin yıllar itibariyle artacağı beklenmektedir. Yatırım artış ile birlikte çıktı ile girdi arasındaki fark artmaya devam edecektir. Bu senaryo uygulaması ile bölgede tarımsal işgücüne olan talep tarım dışı işgücüne olan talepten daha fazla artmaktadır. Yatırımlar sonucunda bölge içi tüketim değeri de tarımsal ürünler lehine olacaktır.

Bölgeye yapılacak yatırımlar genel olarak değerlendirilecek olursa, kamu kesimi yatırımları özel kesim yatırımlarını bölgeye çekecektir. Yeni yatırım olanakları yeni iş imkanları oluşturacaktır. Ancak yatırımlar tarımsal istihdamın tarım dışı istihdamdan daha fazla artmasına yol açacaktır. Bu da niteliksiz işgücünün istihdam edilmesi anlamına gelmektedir. Çıktı ile girdi arasındaki fark olan katma değer artısı diğer senaryo uygulamasına göre daha az olacağından; hem karllık hem de işçilere ödenen ücrette yükselme fazla olmayacaktır. TRA1 bölgesi ile diğer bölgeler arasındaki ortalama ücret fark1 giderek artacaktır. Tarımsal bölge içi tüketim tarım dışı tüketime göre daha fazla artacaktır.

Çalışmada ikinci senaryo uygulaması olarak yatırım artı̧larının verimlilik artışı ile desteklenmesi belirlenmiştir. Senaryo 2'de yatırımların bölgede verimliliği, tarım sektöründe $\% 0,5$; tarım dışı sektörlerde ise $\% 0,7$ oranında geliştirileceği hipotez edilmektedir. Verimlilik artısı ile birlikte çıtı ile girdi arasındaki fark olarak tanımlanan katma değerin yatırım artışından daha fazla artış göstereceği tahmin edilmektedir. Bu senaryo ile bölgede işgücüne olan talep artmakta, ancak bu artşsta dikkat çeken nokta verimlilik artışlarının bölgede tarımsal işgücüne olan talebi azaltırken tarım dışı işgücüne olan talebi artırmasıdır. 
Bölgeye yapılacak yatırım artışının verimlilik artısı ile desteklenmesi durumunda, kamu kesimi yatırımları özel kesim yatırımlarını bölgeye çekecektir. Yeni yatırım olanakları yeni iş imkanları oluşturacaktır. Ancak bu senaryo uygulaması ile tarım dışı istihdam tarımsal istihdama göre daha fazla artacaktır. Bu da daha nitelikli işgücünün istihdam edilmesi anlamına gelmektedir. Çıktı ile girdi arasındaki fark olan katma değer artışı diğer senaryoya göre daha fazla artacağından hem karll1ık hem de işçilere ödenen ücrette yükselme fazla olacaktır. TRA1 bölgesi ile diğer bölgeler arasındaki ortalama ücret farkı giderek azalacaktır. Tarım dışı tüketim tarımsal tüketime göre daha fazla artacaktır.

Onuncu Kalkınma Planı'nda belirtildiği gibi yatırım uygulamalarında maliyet-etkinlik, hesap verebilirlik, şeffaflık, öngörülebilirlik, esneklik, atıl kapasite oluşturulmaması ile verimlilik ilkeleri gözetilerek istihdam, yüksek katma değer ve ihracat artısına önem verilmelidir. Bölgeler arasındaki gelişmişlik farklarının giderilmesi ancak verimlilik, işgücü niteliğinin artırılması, ihracatta ürün çeşitliliğine gidilmesi gibi faktörlerle mümkün olacaktır.

Bu çalışmada yatırım ve verimlilik artı̧larının bölge ekonomisi üzerine etkileri değerlendirilmiştir. Bölgesel kalkınma için hem yatırımlar hem de verimlilik artışları birbirlerini tamamlayarak bölgeye önemli katkılar sağlayacaktır. Yatırımların ekonomik ve sosyal etkisi etkinliğine bağlıdır. Verimlilik artışı büyümeye doğrudan katkı sağlamasının yanında kıt kaynakların etkin ve sürdürülebilir biçimde kullanılmasını sağlayacaktır. Burada amaç kamu kaynaklarının israf edilmeyecek şekilde kullanılması olmalıdır. Onuncu Kalkınma Planı'nda da hedeflendiği gibi kamu sermayeli işletmelerin kamuya yük getirmeden verimlilik ilkesi çerçevesinde faaliyet göstermeleri gerekmektedir. Nitekim kamu yatırımları vergilerle finanse edilmektedir.

Türkiye'de hesaplanabilir genel denge modeli üzerine yapılan çalışmalardan Telli (2004) Türkiye ekonomisi için makro düzeyde reel sosyal hesaplar matrisi üretilmesi için tutarlı bir çerçeve geliştirmiştir. Çavdaroğlu (2007) da reel sosyal hesaplar matrisinin finansal sosyal hesaplar matrisine dönüştürülebilmesi için mali fon akım tablolarını oluşturmuştur. Erten (2009) ise reel sosyal hesaplar matrisi kurgusunun makro düzlemden daha detaylı sektörel düzleme taşınmasını sağlamıştır. Yeldan vd. (2012) tarafindan kurgulanan model Türkiye için ilk bölgesel genel denge modelidir. Bu çalışmada TRA1 Düzey 2 bölgesi oluşturulan sosyal hesaplar matrisi bir Düzey 2 bölgesi için oluşturulan ilk matristir. Oluşturulan bu matris referans alınarak diğer Düzey 2 bölgeleri için de sosyal hesaplar matrisi elde edilerek çeşitli politikaların genel ekonomi üzerindeki etkilerinin hesaplanabilir genel denge modeli çerçevesinde çözülmesi mümkün olacaktır. 
Bölgesel sorunların çözülmesine katkı sağlayabilecek çeşitli politikaların etkilerinin geliştirilen veri altyapısı ile çözülebilmesi için sektörlerin, hanehalkı hesabının, firma hesaplarının daha detaylandırılması faydalı olacaktır. Bölgesel düzeyde veri yetersizliğinden dolayı bu çalışmada hanehalkı ve firma hesabı birleştirilip özel kesim hesabı olarak ele alınmakta ve tarım ve tarım dışı olmak üzere iki sektörlü bir yapı tercih edilmektedir. Bölgesel kalkınma konusu sadece geliştirilen veri altyapısı kullanılarak modelin uygulamasının yapıldığ bir konudan ibaret olarak görülmemelidir. Sosyal bilimlerde kullanılan sayısal modelleme çalşsmalarında, politika sonuçları kullanılan modelin cebirsel özelliklerine duyarlıdır. Bu yüzden politika önermelerinin modellenen bölge ekonomileri için daha gerçekçi olabilmesi için modellerin sürekli güncellenmesi gerektiği esastır. 


\section{Kaynakça}

Aghian, P. ve Howitt, P. (2009). Economics of Growth, MIT Press, Cambridge.

Aschauer, D. A. (1989). "Is Public Expenditure Productive?". Journal of Monetary Economics, 23: 177-200.

Bautista, R. M. (1988). "General Equilibrium Effects of Increasing Productivity in Philippine Manufacturing, With Special Reference to Food Processing". Journal of Philippine Development, Number Twenty Seven, XV(2): 223-243.

Calderón, C. ve Servén, L. (2004). The Effects of Infrastructure Development on Growth and Income Ditribution, WPS3400.

Costa, J. S., Ellson, R. W. ve Martin, R. C. (1987). "Public Capital, Regional Output, And Development: Some Empirical Evidence". Journal of Regional Science, 27(3): 419-437.

Coutinho, R. M. ve Gallo, G. M. (1996). Do Public and Private Investment Stand in Each Other's Way. (unpublished paper), Washington, DC.

Çavdaroğlu, H. S. (2007). Türk Ekonomisinde Sektörler Arası Mali Fon Akımlarr. Planlama Uzmanlığı Tezi, Kalkınma Bakanlığı, Ankara.

Duffy-Deno, K. T. ve Eberts, R. W. (1991). "Public Infrastructure and Regional Economic Development: A Simulations Equations Approach". Journal Of Urban Economics, 30: 329-343.

Erten, H. (2009). Türkiye İçin Sektörel Sosyal Hesaplar Matrisi Üretme Yöntemi ve İstibdam Üzerine Bir Hesaplanabilir Genel Denge Modeli Uygulaması. Dpt Uzmanlık Tezi, Ankara.

Fougere, M., Merette, M., Harvey, S., Poitras, F. (2004). “Ageing Population and Immigration in Canada: An Analysis with a Regional CGE Overlapping Generations Model". Canadian Journal of Regional Science, 27: 209-236.

Gallagher, M. (1991). Rent-Seeking and Economic Growth in Africa. Westview Press Inc.

Garcia-Milà, T. (1992). "The Contribution of Publicly Provided Inputs to States' Economies". Regional Science and Urban Economics, 22(2): 229241.

Ghazanchyan, M., Stotsky, J. (2013). "Drivers of Growth: Evidence from sub-Saharan Africa". IMF Working Paper, WP/13/236, International Monetary Fund, Washington. 
Gupta, S., Kangur, A., Papageorgiou, C. ve Wane, A. (2014). "EfficiencyAdjusted Public Capital and Growth". World Economic Development, 57: 164-78.

Hansen, N. (1965). "Unbalanced Growth And Regional Development". Western Economic Journal, 4: 3-14.

Hulten, C. R. ve Schwab, R. M. (1984). "Regional Productivity Growth in U.S. Manufacturing: 1951-78". The American Economic Review, 74(1): 152162.

Johansen, L. (1960). A Multi-Sectoral Study Of Economic Growth. Amsterdam, North-Holland.

Khan, M. S. ve Reinhart, C. M. (1990). "Private Investment and Economic Growth in Developing Countries". World Development, 18(1): 19-27.

Khan, M. S., Kumar, M. S. (1993). Public and Private Investment and the Convergence of Per Capita Incomes in Developing Countries. IMF Working Paper, No. 93/51, International Monetary Fund, Washington DC.

Khan, M. S. ve Kumar, M. S. (1997). "Public Investment, Productivity, And Economic Growth In Developng Countries". Journel of Public Budgeting, Accounting \& Financial Management, 9(3): 440-466.

Kim, E. ve Kim, K. (2002). "Impacts of Regional Development Strategies on Growth And Equity of Korea: A Multiregional CGE Model". The Annals of Regional Science, 36: 165-180.

Kim, E. ve Kim, K. (2003). "Impacts of the Development of Large Cities on Economic Growth And Income Distribution in Korea: A Multiregional CGE Model", Papers in Regional Science, 82: 101-122.

King, R. G. ve Levine, R. (1992). Financial Indicators and Growth in a Cross-Section of Countries. The World Bank Working Paper Series (WPS 819), Washington.

Li, W., Li, X., Wang, W. ve Guangbao, Z. (2010). Fiscal Policy, Regional Disparity And Poverty in Chine: A General Equilibrium Approcah, MPIA Working Paper.

Liu, C. C. (2006). "Evaluating The Impacts of Tainan Science-Based Industrial Park on the Southern Region in Taiwan". The Empirical Economics Letters, 5(1): 55-66.

Lofgren, H., Harris, R. L., Robinson, S., Thomas, M. ve El-Said, M. (2002). A Standard Computable General Equilibrium (Cge) Model in GAMS, Microcomputers İn Policy Research 5, International Food Research Institute. 
Lu, W. (1996). "Public Infrastructure And Regional Economic Development: Evidence From China", Pacific Economic Papers, No. 258.

Lynde, C. ve Richmond, J. (1993). "Public Capital And Total Factor Productivity", International Economic Review, 34(2): 401-414.

Márquez, M. A., Ramajo, J. ve Hewings, G. J. D. (2011). "Public Capital And Regional Economic Growth: A SVAR Approach fort he Spanish Regions”, Investigaciones Regionales, 21: 199-223.

Mostert, J. W. M. ve Heerden, J. H. (2015). “A Computable General Equilibrium (CGE) Analysis of the Expenditure on Infrastructure in the Limpopo Economy in South Africa", Int Adv Res, 21: 227236.

Munnell, A. H. (1990). "Why Has Productivity Growth Declined? Productivity and Public Investment", New England Economic Review, $3(22)$.

Munnell, A. H. (1992). "Policy Watch Infrastructure Investment And Econımic Growth", Journal of Economic Perspectives, 6(4): 189-198.

Odedokun, M. O. (1992). Multi-country Evidence on the Effects of Macroeconomic, Financial and Trade Policies on Efficiency of Resource Utilization in Developing Countries. IMF Working Paper, Paper No 92/53, Washington.

Rosik, P. (2006). "Public Capital And Regional Economic Growth", Poznań University of Economics Review, 6(1): 69-93.

Sakamoto, H. (2012). "CGE Analysis of Transportation Cost And Regional Economy: East Asia And Northern Kyushu”, Regional Science Inquiry Journal, IV(1): 121-140.

Serven, L., Solimano, A. (1990). Private Investment and Macroeconomic Adjustment: Theory, Country Experience, and Policy Implications. Policiy, Research And External Affairs Workinp Paper, Washington DC.

Telli, Ç. (2004). Sosyal Hesaplar Matrisi Üretme Yöntemi ve Türkiye Uygulaması, Uzmanlık Tezi, Devlet Planlama Teşkilatı Yıllık Programlar ve Konjonktür Değerlendirme Genel Müdürlüğü Planlama, Ankara.

Thaipraset, N., Faulk, D., Hicks, M. J. (2013). “A Regional Computable General Equilibrium Analysis of Property Tax Rate Caps and A Sales Tax Rate Increase in Indiana". Public Finance Review, 41(4): 446472.

Upadhyaya, M. P. (1995). A Computable General Equilibrium Analysis of Alternative Tax Policies in the State of W ashington. UMI Company, UMI Microform 9632274, USA. 
Yamano, N. ve Ohkawara, T. (2000). "The Regional Allocation of Public Investment: Efficiency or Equity?”, Journal of Regional Science, 40(2): 205-229.

Yeldan, E., Taşcı, K., Voyvoda, E. ve Özsan, M. E. (2012). Orta Gelir Turağı'ndan Çkıs: Hangi Türkiye? Cilt 1: Makro/ Sektörel/ Bölgesel Analiz: Türkonfed, İstanbul.

Yeldan, E., Taşc1, K., Voyvoda, E. ve Özsan, M. E. (2013). Orta Gelir

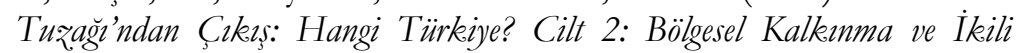
Tuzaktan Çkış Stratejileri. Türkonfed, İstanbul.

\section{İnternet Kaynakları}

DAP Bölge Kalkınma İdaresi Başkanlığı, www.dap.gov.tr, (erişim tarihi: 01.01. 2017).

Dünya Bankas1, www.worldbank.org., (erişim tarihi: 01.01. 2017).

Gelir İdaresi Başkanlığ1, www.gib.gov.tr., (erişim tarihi: 01.01. 2017).

Hazine Müsteşarlığ1, www.hazine.gov.tr., (erişim tarihi: 01.01. 2017).

International Monetary Fund, www.imf.org., (erişim tarihi: 01.01. 2017).

Kalkınma Bakanlığı, www.kalkinma.gov.tr., (erişim tarihi: 01.01. 2017).

Kuzeydoğu Anadolu Kalkınma Ajansı (KUDAKA), www.kudaka.org.tr., (erişim tarihi: 01.01. 2017).

Türkiye İstatistik Kurumu, www.tuik.gov.tr., (erişim tarihi: 01.01. 2017).

Türkiye Cumhuriyet Merkez Bankası, www.tcmb.gov.tr., (erişim tarihi: 01.01. 2017).

Türkiye İhracatçılar Meclisi (TIM), www.tim.org.tr., (erişim tarihi: 01.01. 2017). 
Bölgesel Kalkınmada Yatırım ve Verimlilik: TRA1 Bölgesi İçin Hes...

\section{Ekler}

EK 1. 2016 Türkiye İki Bölge ve İki Sektörlü Sosyal Hesaplar Matrisi

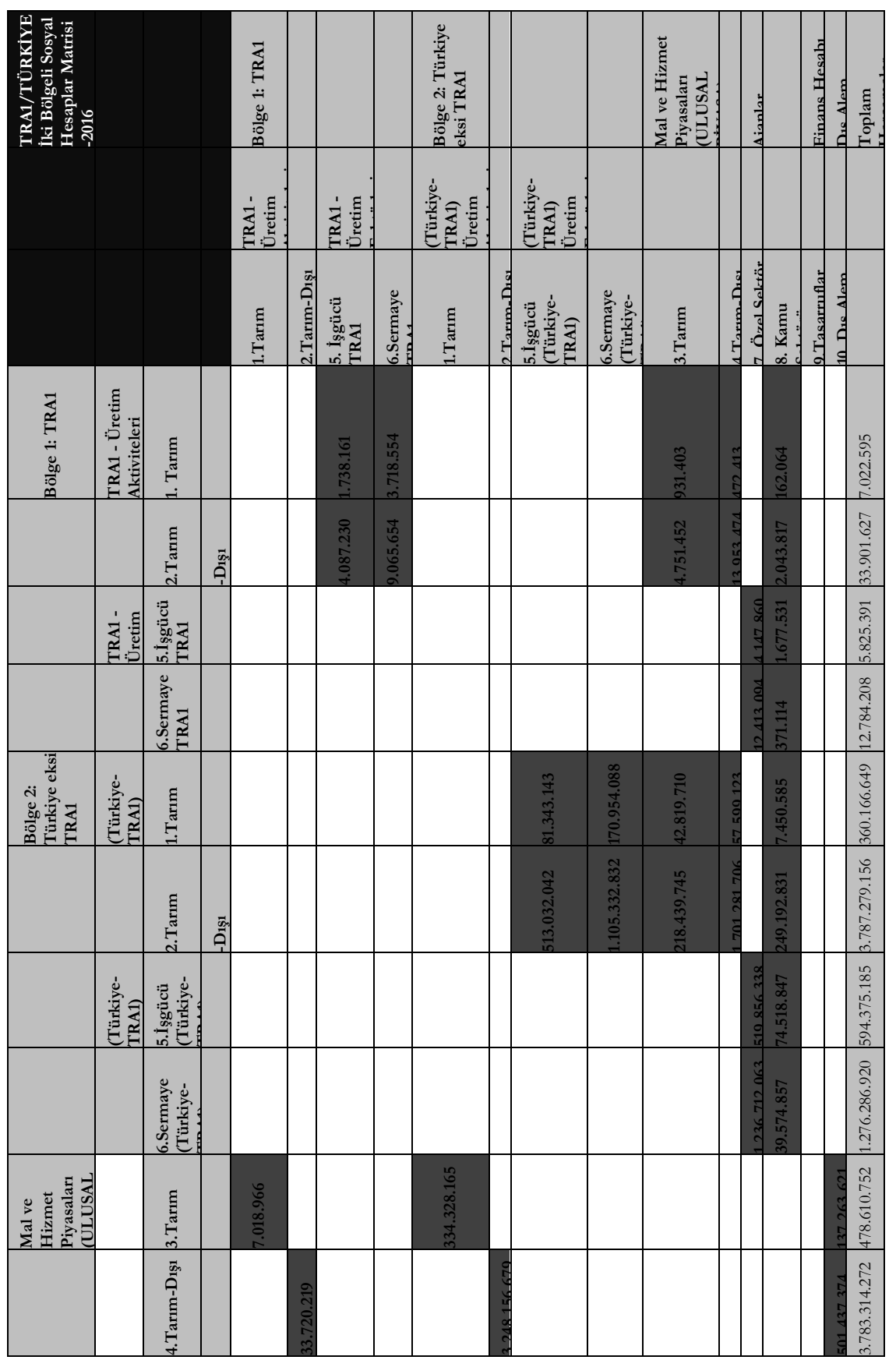


Muammer YAYLALI, Zeynep KARACA

\begin{tabular}{|c|c|c|c|c|c|c|c|c|c|c|c|c|c|}
\hline & 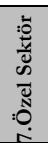 & & & & & & & & & 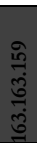 & & & 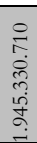 \\
\hline$\frac{\bar{E}}{4} \tilde{z}$ & & & & & & & & & & & & & \\
\hline & 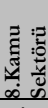 & & & & & & & & & 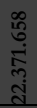 & & & 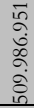 \\
\hline 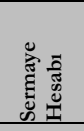 & 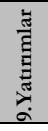 & & & & & & & & & 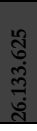 & & & 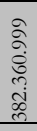 \\
\hline & 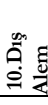 & శ్రి & & & & 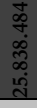 & & & & & & & $\begin{array}{l}\overrightarrow{5} \\
0 \\
\infty \\
0 \\
\overrightarrow{5} \\
5\end{array}$ \\
\hline & 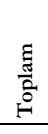 & 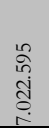 & 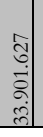 & $\begin{array}{l}\overrightarrow{5} \\
\text { ते } \\
\text { iे } \\
\text { in } \\
\text { in }\end{array}$ & 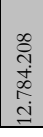 & 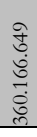 & 웡 & 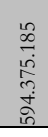 & 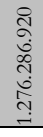 & 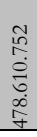 & 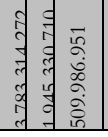 & : & \\
\hline
\end{tabular}




\section{EK 2. Modelin Denklemleri}

\section{Fiyat Bloğu}

Ithalat fiyatı

$$
P_{i}^{M}=P_{i}^{W M} \cdot \varepsilon\left(1+t m_{i}\right)
$$

İhracat fiyat1

$$
P_{i, r}^{E}=P_{i, r}^{W E} \cdot \varepsilon\left(1-t x_{i, r}\right)
$$

Bileşik mal fiyatı

$$
P C_{i}=\left[P_{i}^{D}\left(\frac{D C_{i}}{C C_{i}}\right)+P_{i}^{M}\left(\frac{M_{i}}{C C_{i}}\right)\right] \cdot\left[1+\text { saltax }_{i}\right]
$$

Yurt içi mal fiyatı

$$
P D C_{i}=\sum_{r} P_{i, r}^{D} D C_{i, r} / D C C_{i}
$$

Bölgesel üretim fiyatı

$$
P X_{i, r}=\left[P_{i, r}^{D}\left(\frac{D C_{i, r}}{X S_{i, r}}\right)+P_{i, r}^{E}\left(\frac{E_{i, r}}{X S_{i, r}}\right)\right]
$$

Bölge 1 (y) net katma değer fiyatı

$$
P V A_{i, r y}=\left(1-\operatorname{protax}_{i, r y}\right) .\left(P X_{i, r y}\right)-\sum_{j} P C_{j} I O R Y_{j, i}
$$

Bölge 2 (z) net katma değer fiyatı

$$
P V A_{i, r z}=\left(1-\operatorname{protax}_{i, r z}\right) \cdot\left(P X_{i, r z}\right)-\sum_{j} P C_{j} I O R Z_{j, i}
$$

Fiyat endeksi

$$
\text { PINDEX }=\sum_{i} \text { PWTS }_{i} P C_{i}
$$

\section{Üretim ve Faktör Bloğu}

Bölgesel mal üretimi

$$
X S_{i, r}=\left(A_{x x r} K_{i, r}\right)^{B_{x i r} l d_{i, r}{ }^{\left(1-B_{x i r} r\right.}}
$$

Bölgesel ücret

$$
W_{r}=\frac{\left(1-B_{x i r}\right) \cdot P V A_{i, r} \cdot X S_{i, r}}{W D I S T_{i, r} \cdot L D_{i, r} \cdot\left(1+\operatorname{sstax}_{r}\right)}
$$

Bölgesel kar oranı

$$
R K_{r}=\frac{B_{x i r} \cdot P V A_{i, r} \cdot X S_{i, r}}{R K D I S T_{i, r} \cdot K_{i, r}}
$$

İşücü piyasa dengesi

$$
U N E M P_{r}=L S U P_{R}-\sum_{i} L D_{i, r}
$$


Sermaye piyasası dengesi

$$
\sum_{i} K_{i, r}=K S U P P_{r}
$$

Ticaret Bloğu

Sabit dönüşüm fonksiyonu

$$
X S_{i, r}=A_{t i r}\left[\beta_{t i r} E_{i r}^{\rho t i r}+\left(1-\beta_{t i r}\right) D C_{i r}^{\rho t i r}\right] \frac{1}{\rho t i r}
$$

Armington fonksiyonu

$$
C C_{i r}=A_{c i r}\left[\beta_{c i r} M_{i r}^{-\rho c i r}+\left(1-\beta_{c i r}\right) D C_{i r}^{-\rho c i r}\right] \frac{1}{\rho c i r}
$$

Kar maksimizsayonu koşulu

$$
\frac{E_{i r}}{D C_{i r}}=\left[\frac{P_{i r}^{E}}{P_{i r}^{D}} \cdot \frac{\left(1-\beta_{t i r}\right)}{\beta_{t i r}}\right]^{\frac{1}{\rho t i r-1}}
$$

Maliyet minimizasyonu koşulu

$$
\frac{M_{i r}}{D C_{i r}}=\left[\frac{P_{i r}^{D}}{P_{i r}^{M}} \cdot \frac{\beta_{c i r}}{\left(1-\beta_{c i r}\right)}\right]^{\frac{1}{\rho c i r+1}}
$$

İhracatçı olmayan sektörler için

$$
D C_{i r}=X S_{i r}
$$

İthalatçı olmayan sektörler için

$$
C C_{i r}=D C_{i r} \cdot\left(1+\text { salt }_{i r}\right)
$$

\section{Gelir Bloğu}

Özel kesim geliri

$Y=\sum_{i}\left(\left(W_{r} \cdot W_{F D I S T} T_{i r} D_{i r}+\left(1-\operatorname{corprtax}_{r}\right) \cdot R K_{r} \cdot R K D I S T_{i, r} \cdot K_{i, r}\right)\right)+$ GOVTRANS + INTDOM * GDOMDEBT + NPFI - INTFORP * PFORDEBT

Kamu kesimi geliri

$$
\begin{gathered}
\text { GREV }=\text { TOTPROTAX + TOTSALTAX + TARIFF + TOTSSTAX + } \\
\text { TOTCORPTAX + TOTHHTAX + EXTAX }
\end{gathered}
$$

\section{Maliye Bloğu}

Toplam üretim vergisi $\quad$ TOTPROTAX $=\sum_{i} \operatorname{prot}_{i} \cdot P X_{i} \cdot X S_{i}$

Toplam satış vergisi

$$
\text { TOTSALTAX }=\sum_{i} \operatorname{salt}_{i}\left(P_{i}^{D} \cdot D C_{i}+P_{i}^{M} \cdot M_{i}\right)
$$

Toplam gümrük vergisi

$$
\text { TARIFF }=\sum_{i} t m_{i} \cdot P_{i}^{W M} \cdot \varepsilon \cdot M_{i}
$$


Toplam kurumlar vergisi

TOTCORPTAX $=\sum_{i} \operatorname{corpt} \cdot\left(\right.$ PROFP $_{i}+$ PROFG $\left._{i}\right)$

Toplam hanehalk1 gelir vergisi

TOTHHTAX $=$ htax $\cdot Y H H$

Topalm ihracat vergisi

$$
\text { EXTAX }=\sum_{i} t e_{i} \cdot P_{i}^{W E} \cdot \varepsilon \cdot E_{i}
$$

Kamu tüketimi

$$
\text { GOVCON }=\text { gcr } \cdot G D P
$$

Kamu yatırımı

$$
G I N V=\text { gir.GDP }
$$

Kamudan işletmelere transferler

$G t r E E=r t G t r E E \cdot G R E V$

Kamu toplam transferleri GOVTRANS $=$ GtrSSI + GtrHH + GtrEE

Tasarruf Yatırım Dengesi

Özel kesim tasarrufu

$$
\text { PRSAV }=\text { mps } \cdot Y H H \cdot(1-\text { htax })
$$

Kamu kesimi tasarrufu

$G S A V=G R E V-G O V C O N-G O V T R A N S-i r_{F G} \cdot \varepsilon \cdot G F D-i r_{D O M} \cdot G D D$

Kamu yatırım-tasarruf fark1

$$
P I S B=G I N V-G S A V
$$

Kamu borçlanma gereği (KKBG)

KKBG finansmanı

$$
P S B R=P I S B-r t P S B R \cdot G D P
$$

Kamu diş borçlanma $P S B R=D O M B O R+\varepsilon \cdot G O V F B O R$ Ulusal tasarruf-yatırim dengesi $\varepsilon \cdot G O V F B O R=r t G O V F B O R \cdot P S B R$

$P R S A V+G S A V+\varepsilon \cdot F S A V=P R I N V+G I N V$

\section{Talep Bloğu}

Sektörler itibariyle kamu tüketimi

$$
G D_{i}=\frac{\text { gles }_{i} \cdot G O V C O N}{P C_{i}}
$$

Sektörler itibariyle özel tüketim

$$
C D_{i}=\frac{\text { cles }_{i} \cdot(1-m p s) \cdot Y H H \cdot(1-h t a x)}{P C_{i}}
$$

Sektörler itibariyle ara girdi talebi

$$
I N T_{i}=\sum_{j} a_{i j} \cdot X S_{j}
$$

Yurt içi faiz oranı

$$
i r_{D O M}=r t i r_{D O M} \frac{G F D+G D D}{G D P}
$$

Sektörler itibariyle özel yatırım

$$
I D_{i}=\frac{\text { idles }_{i} \cdot P R I N V}{P C_{i}}
$$

Sektörler itibariyle kamu yatırımı

$$
G I D_{i}=\frac{\text { gidles }_{i} \cdot G I N V}{P C_{i}}
$$

Gayrisafi yurtiçi hasıla (GSYH)

$$
G D P=\sum_{i}\left[P C_{i}\left(C D_{i}+G D_{i}+G I D_{i}+I D_{i}\right)+P_{i}^{W E} \cdot \varepsilon \cdot E_{i}-P_{i}^{W M} \cdot \varepsilon \cdot M_{i}\right]
$$




\section{Mal Piyasası Dengesi}

Mal piyasas1 dengesi

$$
C C_{i}=I N T_{i}+C D_{i}+G D_{i}+I D_{i}+G I D_{i}
$$

Ödemeler Dengesi

$\sum_{i} P_{i}^{W M} M_{i}+i r_{F P} \cdot P F D+i r_{F G} \cdot G F D+\frac{E E R P t r R O W}{\varepsilon}=\sum_{i} P_{i}^{W E} E_{i}+R O W t r E E+R O W t r H H+F S A V$ 


\section{EK 3. Modelin Değişkenleri}

PINDEX Fiyat düzeyi

$P C_{i}$

Bileşik mal fiyatı

$P_{i}^{D}$

Toplam yurt içi mal fiyatı

$P_{i, r}^{D}$

Bölgesel mal fiyatı

$P_{i, r}^{E}$

Bölgesel ihracat fiyatı

$P_{i}^{M}$

İthalat fiyat1

$P V A_{i, r}$

Bölgesel net fiyat (katma değer)

$P X_{i, r}$ Bölgesel ürün fiyatı

$P_{i, r}^{W E}$

Dünya ihracat fiyat1

$P_{i}^{W M}$

Dünya ithalat fiyatı

$P_{W T S_{i}}$

Fiyat endeksi ağırlıkları

$\mathrm{CC}_{i}$

Bileşik Mal (Yurt içi özümseme)

$D C_{i}$

Ulusal piyasada yurt içi mal

$D C_{i, r}$ Bölgesel piyasalarda yurt içi mal

$E_{i, r} \quad$ Bölgesel ihracat

$M_{i} \quad$ Ithalat

$X S_{i, r}$ Bölgesel toplam ürün arzı

$G D P$ Gayri safi yurt içi hasıla

$L D_{i, r}$ Bölgesel, sektörler itibariyle iş gücü talebi

\section{$L S U P_{r} \quad$ Bölgesel işgücü arzı}

$K_{i, r}$

$K S U P_{r}$

Wr

$W_{F D I S T}$

katsaylar1
Bölgesel sektörler itibariyle sermaye talebi

Bölgesel sermaye stoku

Bölgesel nominal ücretler

Bölgesel, sektörler itibariyle ücret farklılaşma 
$R_{K D I S T_{i, r}} \quad$ Bölgesel, sektörler itibariyle kar oranı farklılaşma katsayilar1

$R K_{r}$ Bölgesel sektörler itibariyle kar oranı

UNEMP $P_{r} \quad$ Bölgesel işsizlik

$C D_{i} \quad$ Sektörel özel tüketim harcamaları

$G D_{i} \quad$ Sektörel kamu tüketim harcamaları

$I D_{i} \quad$ Sektörel özel yatırım talebi

$G I D_{i} \quad$ Sektörel kamu yatırım talebi

$I N T_{i, r} \quad$ Bölgesel ara malı talebi

EXTAX İhracat vergisi gelirleri

TOTPROTAX Üretim vergisi geliri

TOTSALTAX Satı̧ vergisi geliri

TOTSSTAX Sosyal güvenlik vergisi gelirleri

TOTCORPTAX Kurumlar vergisi gelirleri

TARIFF Gümrük vergisi geliri

TOTHHTAX Toplam gelir vergisi

GREV Toplam kamu geliri

GOVCON Kamu tüketim harcamaları

GOVTRANS Kamu transferleri

GSAV Kamu kesimi tasarrufu

FSAV Diș tasarruflar

PRSAV Özel kesim tasarrufu

mps Özel kesim marjinal tasarruf eğilimi

GFD Kamu kesimi dış borç stoku

PFD Özel kesim diş borç stoku

$G D D$ Kamu kesimi iç borç stoku

PFORDEBT Özel kesim diş borç stoku

INTFORP Özel diş borçlar faiz yükü

INTFORG Kamu dış borçları faiz yükü

INTDOM Yurt içi faiz oranı

GOVFBOR Devlet dış borçlanması

$Y$

NPFI

$M P S$
Özel kesim geliri

Yurt dışından net faktör gelirleri

Özel tasarruf oranı 


\begin{tabular}{|c|c|}
\hline $\begin{array}{l}\text { TOTINV } \\
\varepsilon\end{array}$ & $\begin{array}{l}\text { Toplam yatırımlar } \\
\text { Döviz kuru }\end{array}$ \\
\hline PROFP $_{i}$ & Toplam özel sermaye karı \\
\hline$P_{R O F G}$ & Toplam kamu sermayesi kar1 \\
\hline GINV & Toplam kamu kesimi yatırımı \\
\hline PRINV & Toplam özel kesim yatırımı \\
\hline GtrEE & Kamudan işletmelere yapılan transferler \\
\hline GtrSSI & Bütçeden sosyal güvenlik açıkları finansmanı transferi \\
\hline $\begin{array}{l}\text { GtrHH } \\
\text { transfer }\end{array}$ & Kamu kesiminden hanehalkına yapilan toplam \\
\hline$i r_{F G}$ & Kamu kesimi dış borç faizi \\
\hline$i r_{D O M}$ & Kamu kesimi iç borç faizi \\
\hline$P I S B$ & Kamu kesimi tasarruf-yatırım fark1 \\
\hline$P S B R$ & Kamu kesimi borçlanma gereği \\
\hline GOVFBOR & Kamu kesimi net diş borçlanma \\
\hline$i r_{F P}$ & Özel kesim dış borç faizi \\
\hline EERPtrROW & Firmaların yurtdışına kar transferi \\
\hline ROWtrEE & Yurtdıșından firmalara yapılan transferler \\
\hline ROWtrHH & Yurtdışından hanehalkına yapılan transferler \\
\hline
\end{tabular}




\section{EK 4. Modelin Parametreleri}

$A_{c i} \quad$ Armington fonksiyonu parametresi

$A_{d c i}$

Yurt içi mal fonksiyonu kaydırma parametresi

$A_{\text {tir }}$

CET fonksiyonu kaydırma parametresi

$A_{\text {xir }}$

Üretim fonksiyonu kaydırma parametresi

$B_{c i}$

Armington fonksiyonu kaydırma parametresi

$B_{d c i}$

Yurt içi mal Armington fonksiyonu kaydırma

parametresi

$B_{\text {tir }}$

CET fonksiyonu kaydırma parametresi

$B_{x i r}$

Cobb - Douglas üretim fonksiyonu pay parametresi

cles $_{i}$

Sektörel özel tüketim payları

gles

Sektörel kamu tüketim payları

idles

Sektörel yatırım payları

gidles

Sektörel kamu yatırım payları

$r_{\text {rhoc }}$

Armington fonksiyonu katsayıs1

rhot $_{i, r}$

CET fonksiyonu katsayıs

rhodc $_{i}$

Yurt içi mal fonksiyonu katsayısı

$\operatorname{rrp}_{i, r}$

Bölgelerde sektörler Kar oranı haddi

$\operatorname{shrp}_{i, r}$

Bölgelerde sektörler Kar oranı payı

$d k_{i, r}$

Özel yatırım nihai talebi

$\operatorname{protax}_{i, r}$

Bölgesel üretim vergisi oran1

saltaxi

Satış vergisi oranı

$t m_{i}$

Gümrük vergisi oranı

$t e_{i, r}$

İhracat vergisi oranı

$\operatorname{corptax}_{r}$

Bölgesel kurumlar vergisi oranı 
$\operatorname{sstax}_{r} \quad$ Bölgesel sosyal güvenlik vergisi oran1

Qtir

Sabit dönüşüm fonksiyonu esneklik katsayıs1

IORY

Bölge 1 üretiminde ara girdi payı

IORZ $_{j, i}$

Bölge 2 üretiminde ara girdi pay1

htax

Hanehalkından alınan vergilerin hanehalkı gelirine

oran1

$g c r$

Kamu tüketiminin GSYH'ya oranı

gir

$r t G t r E E$

Kamu yatırımının GSYH içindeki payı

rtPSBR

Üretim teşviklerinin kamu gelirlerine oranı

Tasarruf yatırım farkından borçlanma gereğine geçiş parametresi

rtGOVFBOR

$a_{i j}$

rtir $_{D O M}$

oran1
Kamu dış borçlanmasının borçlanma gereğine oranı

Ara girdi talebi

Yurt içi faiz oranı / (toplam kamu borcu/GSYH) 


\section{EK 5. Baz Durum Hesaplanabilir Genel Denge Modeli Sonuçları, 2016-2023}

\begin{tabular}{|c|c|c|c|c|c|c|c|c|}
\hline $\begin{array}{l}\text { İşGÜCÜ } \\
\text { TALEBİ } \\
\text { (LD) }(\%)\end{array}$ & 2016 & 2017 & 2018 & 2019 & 2020 & 2021 & 2022 & 2023 \\
\hline $\begin{array}{l}\text { TRA1- } \\
\text { Tarım }\end{array}$ & 0.194 & 0.201 & 0.208 & 0.213 & 0.219 & 0.224 & 0.229 & 0.234 \\
\hline $\begin{array}{l}\text { TRA1- } \\
\text { Tarım Dıș1 }\end{array}$ & 0.180 & 0.181 & 0.183 & 0.186 & 0.189 & 0.192 & 0.196 & 0.200 \\
\hline $\begin{array}{l}\text { Diğer- } \\
\text { Tarım }\end{array}$ & 5.533 & 5.616 & 5.712 & 5.821 & 5.945 & 6.086 & 6.241 & 6.423 \\
\hline $\begin{array}{l}\text { Diğer- } \\
\text { Tarım Dış1 }\end{array}$ & 21.729 & 22.041 & 22.400 & 22.811 & 23.279 & 23.810 & 24.382 & 25.054 \\
\hline $\begin{array}{l}\text { İŞLETME } \\
\text { ARTIĞI } \\
\text { (K) (TL) }\end{array}$ & 2016 & 2017 & 2018 & 2019 & 2020 & 2021 & 2022 & 2023 \\
\hline $\begin{array}{l}\text { TRA1- } \\
\text { Tarım }\end{array}$ & 3.719 & 4.164 & 4.536 & 4.851 & 5.123 & 5.364 & 5.590 & 5.807 \\
\hline $\begin{array}{l}\text { TRA1- } \\
\text { Tarım Dış1 }\end{array}$ & 9.066 & 9.855 & 10.520 & 11.098 & 11.617 & 12.098 & 12.559 & 13.023 \\
\hline $\begin{array}{l}\text { Diğer- } \\
\text { Tarım }\end{array}$ & 170.954 & 176.175 & 181.389 & 186.638 & 191.965 & 197.417 & 203.149 & 209.308 \\
\hline $\begin{array}{l}\text { Diğer- } \\
\text { Tarım Dı\$1 }\end{array}$ & 1.105 .333 & 1.138 .344 & 1.171.178 & 1.204 .123 & 1.237 .477 & 1.271 .543 & 1.306 .518 & 1.344 .088 \\
\hline $\begin{array}{l}\text { BÖLGE } \\
\text { İÇİ } \\
\text { TÜKETİ } \\
\text { M (TL) }\end{array}$ & 2016 & 2017 & 2018 & 2019 & 2020 & 2021 & 2022 & 2023 \\
\hline $\begin{array}{l}\text { TRA1- } \\
\text { Tarım }\end{array}$ & 7.019 & 7.668 & 8.208 & 8.668 & 9.069 & 9.429 & 9.769 & 10.095 \\
\hline $\begin{array}{l}\text { TRA1- } \\
\text { Tarım Dış1 }\end{array}$ & 33.720 & 35.811 & 37.617 & 39.236 & 40.738 & 42.171 & 43.573 & 45.006 \\
\hline $\begin{array}{l}\text { Diğer- } \\
\text { Tarım }\end{array}$ & 334.328 & 344.661 & 355.320 & 366.395 & 377.984 & 390.192 & 403.391 & 417.861 \\
\hline $\begin{array}{l}\text { Diğer- } \\
\text { Tarım Diș1 }\end{array}$ & 3.248 .157 & 3.360 .042 & 3.475 .580 & 3.595 .752 & 3.721 .602 & 3.854 .244 & 4.012 .318 & 4.185 .044 \\
\hline $\begin{array}{l}\text { ORTALA } \\
\text { MA } \\
\text { ÜCRET } \\
\text { DÜZEYİ } \\
\text { (TL) }\end{array}$ & 2016 & 2017 & 2018 & 2019 & 2020 & 2021 & 2022 & 2023 \\
\hline TRA1 & 11.072 & 11.281 & 11.460 & 11.623 & 11.779 & 11.934 & 12.146 & 12.380 \\
\hline Diğer & 19.069 & 19.414 & 19.727 & 20.008 & 20.259 & 20.479 & 20.773 & 21.040 \\
\hline $\begin{array}{l}\text { KATMA } \\
\text { DEĞER } \\
\text { (TL) }\end{array}$ & 2016 & 2017 & 2018 & 2019 & 2020 & 2021 & 2022 & 2023 \\
\hline TRA1 & 18.610 & 19.239 & 19.873 & 20.525 & 21.203 & 21.915 & 22.761 & 23.684 \\
\hline
\end{tabular}

Kaynak: Yazarın Kendi Hesaplamaları 
Bölgesel Kalkınmada Yatırım ve Verimlilik: TRA1 Bölgesi İçin Hes...

EK 6. Senaryo 1 Hesaplanabilir Genel Denge Modeli Sonuçları, 20162023

\begin{tabular}{|c|c|c|c|c|c|c|c|c|}
\hline $\begin{array}{l}\text { İşGÜCÜ } \\
\text { TALEBİ (LD) } \\
(\%)\end{array}$ & 2016 & 2017 & 2018 & 2019 & 2020 & 2021 & 2022 & 2023 \\
\hline TRA1- Tarım & 0.194 & 0.209 & 0.220 & 0.231 & 0.241 & 0.250 & 0.259 & 0.267 \\
\hline TRA1-Tarım Dışı & 0.180 & 0.178 & 0.178 & 0.179 & 0.181 & 0.184 & 0.187 & 0.191 \\
\hline Diğer-Tarım & 5.533 & 5.610 & 5.703 & 5.813 & 5.938 & 6.082 & 6.252 & 6.449 \\
\hline Diğer-Tarım Dıșı & 21.729 & 22.031 & 22.390 & 22.808 & 23.280 & 23.820 & 24.455 & 25.190 \\
\hline $\begin{array}{l}\text { IŞLETME } \\
\text { ARTIĞI (K) } \\
\text { (TL) }\end{array}$ & 2016 & 2017 & 2018 & 2019 & 2020 & 2021 & 2022 & 2023 \\
\hline TRA1- Tarım & 3.719 & 4.787 & 5.681 & 6.432 & 7.072 & 7.629 & 8.139 & 8.613 \\
\hline TRA1-Tarım Dışı & 9.066 & 10.741 & 12.048 & 13.100 & 13.976 & 14.747 & 15.450 & 16.127 \\
\hline Diğer-Tarım & 170.954 & 175.891 & 180.872 & 185.935 & 191.145 & 196.629 & 202.469 & 208.749 \\
\hline Diğer-Tarım Dışı & 1.105 .333 & 1.137 .120 & 1.168 .966 & 1.201 .102 & 1.233 .779 & 1.267 .745 & 1.303 .860 & 1.342 .488 \\
\hline $\begin{array}{l}\text { BÖLGE İÇİ } \\
\text { TÜKETİ } \\
\text { (TL) }\end{array}$ & 2016 & 2017 & 2018 & 2019 & 2020 & 2021 & 2022 & 2023 \\
\hline TRA1- Tarim & 7.019 & 8.535 & 9.810 & 10.892 & 11.868 & 12.746 & 13.603 & 14.426 \\
\hline TRA1-Tarım Dıș1 & 33.720 & 37.928 & 41.227 & 44.110 & 46.648 & 49.010 & 51.380 & 53.752 \\
\hline Diğer-Tarım & 334.328 & 344.182 & 354.484 & 365.315 & 376.835 & 389.309 & 402.914 & 417.858 \\
\hline Diğer-Tarım Dışı & 3.248 .157 & 3.357 .113 & 3.470 .641 & 3.589 .534 & 3.721 .310 & 3.869 .215 & 4.030 .000 & 4.209.092 \\
\hline $\begin{array}{l}\text { ORTALAMA } \\
\text { ÜCRET } \\
\text { DÜZEYİ (TL) }\end{array}$ & 2016 & 2017 & 2018 & 2019 & 2020 & 2021 & 2022 & 2023 \\
\hline TRA1 & 11.072 & 11.315 & 11.494 & 11.622 & 11.767 & 11.940 & 12.128 & 12.356 \\
\hline Diğer & 19.069 & 19.414 & 19.726 & 20.046 & 20.335 & 20.634 & 20.923 & 21.183 \\
\hline $\begin{array}{l}\text { KATMA } \\
\text { DEĞER (TL) }\end{array}$ & 2016 & 2017 & 2018 & 2019 & 2020 & 2021 & 2022 & 2023 \\
\hline TRA1 & 18.610 & 19.266 & 19.900 & 20.532 & 21.239 & 22.036 & 22.906 & 23.881 \\
\hline
\end{tabular}

Kaynak: Yazarın Kendi Hesaplamaları 
EK 7. Senaryo 2 Hesaplanabilir Genel Denge Modeli Sonuçları, 20162023

\begin{tabular}{|c|c|c|c|c|c|c|c|c|}
\hline $\begin{array}{l}\text { İşGÜCÜ } \\
\text { TALEBİ (LD) } \\
(\%)\end{array}$ & 2016 & 2017 & 2018 & 2019 & 2020 & 2021 & 2022 & 2023 \\
\hline TRA1- Tarım & 0.194 & 0.204 & 0.212 & 0.221 & 0.228 & 0.236 & 0.242 & 0.249 \\
\hline TRA1-Tarım Dışı & 0.180 & 0.183 & 0.186 & 0.190 & 0.194 & 0.198 & 0.203 & 0.209 \\
\hline Diğer-Tarım & 5.533 & 5.616 & 5.713 & 5.824 & 5.955 & 6.106 & 6.284 & 6.493 \\
\hline Diğer-Tarım Dışı & 21.729 & 22.042 & 22.419 & 22.840 & 23.342 & 23.924 & 24.611 & 25.423 \\
\hline $\begin{array}{l}\text { İŞLETME } \\
\text { ARTIĞI (K) } \\
\text { (TL) }\end{array}$ & 2016 & 2017 & 2018 & 2019 & 2020 & 2021 & 2022 & 2023 \\
\hline TRA1- Tarım & 3.719 & 4.180 & 4.566 & 4.900 & 5.194 & 5.457 & 5.699 & 5.931 \\
\hline TRA1-Tarım Dışı & 9.066 & 9.839 & 10.492 & 11.060 & 11.576 & 12.068 & 12.559 & 13.062 \\
\hline Diğer-Tarım & 170.954 & 176.165 & 181.313 & 186.555 & 191.932 & 197.551 & 203.539 & 210.015 \\
\hline Diğer-Tarım Dışı & 1.105 .333 & 1.138 .355 & 1.171.281 & 1.204 .438 & 1.238 .661 & 1.274 .351 & 1.312 .476 & 1.353 .822 \\
\hline $\begin{array}{l}\text { BÖLGE IÇİ } \\
\text { TÜKETIM } \\
\text { (TL) } \\
\end{array}$ & 2016 & 2017 & 2018 & 2019 & 2020 & 2021 & 2022 & 2023 \\
\hline TRA1- Tarım & 7.019 & 7.758 & 8.414 & 9.007 & 9.570 & 10.095 & 10.599 & 11.094 \\
\hline TRA1-Tarım D1ş̣1 & 33.720 & 35.999 & 38.011 & 39.858 & 41.734 & 43.603 & 45.535 & 47.633 \\
\hline Diğer-Tarım & 334.328 & 344.648 & 356.208 & 368.388 & 382.010 & 397.412 & 414.977 & 434.701 \\
\hline Diğer-Tarım D1şı & 3.248 .157 & 3.360 .131 & 3.476 .913 & 3.605 .195 & 3.742 .435 & 3.897 .151 & 4.070 .147 & 4.261 .010 \\
\hline $\begin{array}{l}\text { ORTALAMA } \\
\text { ÜCRET } \\
\text { DÜZEYİ (TL) }\end{array}$ & 2016 & 2017 & 2018 & 2019 & 2020 & 2021 & 2022 & 2023 \\
\hline TRA1 & 11.072 & 11.183 & 11.290 & 11.400 & 11.522 & 11.678 & 11.858 & 12.072 \\
\hline Diğer & 19.069 & 19.414 & 19.721 & 19.993 & 20.271 & 20.558 & 20.813 & 21.059 \\
\hline $\begin{array}{l}\text { KATMA } \\
\text { DEĞER (TL) }\end{array}$ & 2016 & 2017 & 2018 & 2019 & 2020 & 2021 & 2022 & 2023 \\
\hline TRA1 & 18.610 & 19.249 & 19.909 & 20.623 & 21.381 & 22.233 & 23.184 & 24.226 \\
\hline
\end{tabular}

Kaynak: Yazarın Kendi Hesaplamaları 